\title{
Economics in the Backyard: How Much Convergence is there between China and her Special Regions?
}

\author{
By \\ Andrew Hughes Hallett ${ }^{\ddagger}$ \\ and \\ Christian Richter
}

\begin{abstract}
This paper tests the hypothesis that the links and dependency relationships between China and her special regions have changed over the past 20 years with the industrialisation of China, and the emergence of Taiwan as a source of investment and sophisticated manufactures, and Hong Kong as financial centre and supplier of services. Has this changed the size and direction of spillovers in the region, and has it curtailed or eliminated American economic leadership?

We use time-varying spectral methods to decompose the links between 6 advanced Asian economies and the US. We find: (a) the links with the US have been weakening, while those within a bloc based on China have strengthened; (b) that this is not new - it has been happening since the 1980 s, but has now been reversed by the surge in trade; (c) that Taiwan is more integrated with, and dependent on the Chinese economy, while Hong Kong continues her separate development based on specialisation and comp-arative advantage; (d) that the links with the US are rather complex, with the US able to shape the cycles elsewhere through her control of monetary conditions, but the China zone able to control the size of their cycles; and (e) there appears to be no real evidence that pegged exchange rates encourage convergence; in fact the reverse may be true.
\end{abstract}

Keywords: Spectral Analysis, Coherence, Spillover Gains, Business Cycle Relationships JEL Classification: C22, C29, C49, F43, O49

February 2009

$¥$ Hughes Hallett: George Mason University, University of St Andrews and CEPR; School of Public Policy, 4400 University Drive, Fairfax, VA 22030, USA, Tel: +1-703-933-9123, Email: ahughesh@gmu.edu; Richter: School of Economics, Kingston University, Kingston, KT1 2EE, UK, Tel: +44-(0)20-8417-9000, Email: c.richter@kingston.ac.uk. Richter gratefully acknowledges financial support from the Jubiläumsfond of the Austrian National Bank. We are especially grateful to Richard Burdekin and Kishen Rajan for comments and suggestions. 


\section{Introduction}

China has long claimed political jurisdiction over her two special regions, Hong Kong and Taiwan. But can the same claim be made for a natural jurisdiction over their economies? This paper tries to reach a judgment on that issue; we do not touch the politics of it.

Ironically, it would appear that the local populations of these regions have come to accept the economic arguments for integration or a closer relationship with China, especially since the 2008 elections in Taiwan; but remain unconvinced by the political arguments. This is based no doubt on the economic reality that the emergence of China as one of the world's largest trading economies, the increasing sophistication of Taiwan as an investment and manufacturing centre, and of Hong Kong as a supplier of finance, investment and services, has changed the dependency relationships between many economies in the Asia-Pacific region. It used to be that the US was regarded at the dominant economy in the region, and hence the locomotive, or economy of first resort, through her big consumption of final and intermediate products, trade in sophisticated manufactures, and her supply of investment capital and financial stability when exchange rates were fixed.

But the rise of China as a major supplier of cheap manufactures and intermediates, of Taiwan as a provider of sophisticated manufactures and source of investment, and Hong Kong as financier and supplier of services may have changed all that. These two economies may have become just as important as trading partners and locomotives for China; and all three may have significant spillovers on the US. Moreover their rapidly expanding stocks of foreign assets, acquired through the large and continuing trade imbalances in the region, gives them a certain influence over monetary conditions and financial stability.

These are the changes we wish to test for here. Enhanced trade and integration effects will come in three parts: increased economic convergence (coherence, correlation); increased impact (or spillovers) from developments in one economy onto another; and stronger lead/lag relationships between economies (a lead for those supplying materials or inter-mediate inputs; a lag for those consuming manufactures, services, or supplying investment goods or finance), as shown in Chaplygin et al (2006). We examine all three in this context; focusing on measures of coherence, gain and phase shifts respectively. We can then ask: to what extent are growth cycles becoming more correlated in the Chinese economic area? Is there evidence of 
cyclical convergence at the business cycle frequency, or at any other frequencies? Does that imply a common business cycle?

We are therefore engaged in an exercise in identifying the linkages between the economies of the Chinese economic area. We are not aware that this has been attempted before, although recent papers have tried to examine the relationships between China and her OECD neighbours. ${ }^{1}$ At present a selective reading of the convergence literature could lead to almost any conclusion, and to find an appropriate way to measure the extent and characteristics of the linkages/dependencies between economies is an important problem. In this paper we show how to use a time-varying spectral analysis to determine the degree of convergence at different frequencies and cycles, even where data samples are small and where structural breaks and changing structures are a part of the story. The inconclusive results obtained in the past, particularly for the Euro area, may have been the result of using a correlation analysis which averages the degree of contemporaneous convergence across all frequencies. That is problematic because two economies could share a trend or short term shocks, but show no coherence between their business cycles. ${ }^{2}$ Or because they share similar cycles; but one is a supplier of inputs or capital to the other, so they are out of phase. That would imply low or possibly negative contemporaneous correlations, and give no picture of the true linkage or dependence between them.

In theory, neoclassical growth models show that every economy approaches a steadystate income level determined by the discount rate, the elasticity of factor substitution, the depreciation rate, capital share, and population growth. Once at the steady-state, the economy grows at a constant rate. Thus, to the extent that the determinants of the steady-state are similar across economies, convergence is to be expected. But if those determinants are different, they will not converge. Thus, Mankiw et al. (1992), Dowrick and Nguyen (1989), Wolff (1991), Barro and Sala-I-Martin (1991; 1992), and Quah (1993) find evidence of convergence for a sample of OECD countries at similar levels of development over the years 1960-1985. But they reject that hypothesis in a wider sample of 75 economies whose structures and levels of uncertainty vary a good deal more. Similarly, Chauvet and Potter (2001) report that the US business cycle was in line with the G7 from the mid 70s, but diverged thereafter. Likewise Stock and Watson (2002; 2005), Hughes Hallett and Richter

\footnotetext{
${ }^{1}$ See Sato and Zhang (2006), Shin and Sohn (2006), Shin and Wang (2004), and Kocenda and Hanousek (1998).

${ }^{2}$ As shown by the results in Fidrmuc and Batorova (2008).
} 
(2006) find divergence caused by structural breaks, and argue that cyclical convergence is a global rather than regional phenomenon. In that vein, Artis and Zhang (1997), Frankel and Rose (1998) and Prasad (1999) have all argued that if exchange rates are pegged, and trade and financial links intensify, business cycles are likely to converge. But in practice, Inklaar and de Haan (2000) do not find any evidence for a common business cycle in the Eurozone. Likewise Gerlach (1989), and Baxter and Kouparitsas (2005), find no evidence of convergence among the OECD economies as exchange rates stabilised or trade increased (see also: Doyle and Faust, 2003; Kalemli-Ozcan et al., 2001; Peersman and Smets, 2005) provide further evidence in the same direction ${ }^{3}$.

A common feature of all the studies cited above is that the results are sensitive to: a) the choice of coherence measure (correlation, concordance index); b) the choice of cyclical measure (classical, deviation or growth cycles); and c) the detrending measure used (linear, Hodrick-Prescott filter, band pass etc). This sensitivity to the detrending technique is a serious difficulty highlighted in particular by Canova and Dellas (1993) and Canova (1998). The advantages of using a time-frequency approach are therefore:

i) It does not depend on any particular detrending technique, so we are free of the lack of robustness found in many recent studies.

ii) Our methods also do not have an "end-point problem" - no future information is used, implied or required as in band-pass or trend projection methods.

iii) There is no arbitrary smoothing parameter, such as in the HP algorithm, equivalent to an arbitrary band-pass selection (Artis et al., 2004).

iv) We use a coherence measure which generalises the conventional correlation and concordance measures.

Any spectral approach is tied to a model based on a weighted sum of sine and cosine functions. However, that is not restrictive. Any periodic function may be approximated arbitrarily well over its entire range, and not just around a particular point, by its Fourier expansion (a suitably weighted sum of sine and cosine terms) - and that includes nondifferentiable functions, discontinuities and step functions. Hence, once we have time-varying weights, we can get almost any cyclical shape we want. For example, to get long expansions but short recessions, the typical shape of economic cycles, we need only a regular business

\footnotetext{
${ }^{3}$ Chiefly because structural characteristics and institutions change. In practice it seems that cyclical correlations typically fall with the degree of industrial specialisation, and the latter increases as trade and financial integration intensify (Kalemli-Ozcan et al., 2001; 2003). But market reforms, liberalisation measures, and the extent to which policies are coordinated or made common to a group of economies, may have the opposite effect.
} 
cycle plus a longer cycle whose weight increases above trend but decreases below trend (i.e. varies with the level of activity). This is important because many observers have focused on how the shape of economic cycles has changed over time in terms of amplitude, duration and slope (Harding and Pagan, 2001; Peersman and Smets, 2005; Stock and Watson, 2002). Hence a time-varying spectral approach, capable of separating out changes at different cyclical frequencies in the economy, will be needed to provide the flexibility to capture these features. Similarly, a time varying approach will be necessary if we are to accommodate the structural breaks which must be expected with China emerging as one of the world's largest trading economies; and with the increasing sophistication of the Taiwanese economy in terms of trade in manufactures, components and investment; with increasing financial integration, investment flows and services offered by Hong Kong; changes to the size and composition of trade imbalances with the US; changes to the supply chain of components or inputs to/from China and Taiwan; and a strengthening of monetary institutions. However, if these changes argue for a time-varying approach to measuring the coherence between national economies, then they also argue for a decomposition of the different cycles that make up an economy's performance. One would not expect increased linkages through traded components or manufactures to affect those economies at the same cyclical frequencies as those due to long term investment or short term financing. Hence our choice of a time-frequency approach.

The paper is structured as follows: the next section describes our approach in the time domain. Section 2.2 gives a brief introduction in the time-frequency approach, section 2.3 explains our technique with respect business cycle relationships, and section 3 presents the results for the individual countries/regions, whilst section 4 presents the results with respect to the interdependencies of the different countries/regions. Finally, section 5 concludes.

\section{Empirical Techniques}

\subsection{Estimation in the Time Domain}

For countries in the Asia-Pacific region, and for the US itself, GDP will be expressed in US dollars over the entire sample. We use the IMF's International Financial Statistics data base to ensure that price deflations, seasonal adjustment and exchange rate conversions are applied consistently to each country. Growth rates are then defined, using real GDP data, as:

$$
\mathrm{y}_{\mathrm{t}}=\Delta\left(\log \left(\mathrm{Y}_{\mathrm{t}}\right)\right)=\log \left(\frac{\mathrm{Y}_{\mathrm{t}}}{\mathrm{Y}_{\mathrm{t}-1}}\right)
$$


Next we employ a two step procedure. As Evans and Karras (1996) have shown, if business cycles are to converge, they need to follow the same AR(p) process. We therefore estimate an $\mathrm{AR}(\mathrm{p})$ process for each variable individually. That is, we estimate the data generating process of each of the growth rates separately. Then we estimate the bilateral links between the cycles in those growth rates. In order to allow for the possible changes in the parameters, we will employ a time-varying model by applying a Kalman filter to the chosen AR(p) model as follows:

$$
\mathrm{y}_{\mathrm{t}}=\alpha_{0, \mathrm{t}}+\sum_{\mathrm{i}=1}^{9} \alpha_{\mathrm{i}, \mathrm{t}} \mathrm{y}_{\mathrm{t}-\mathrm{i}}+\varepsilon_{\mathrm{t}}
$$

with

$$
\alpha_{i, t}=\alpha_{i, t-1}+\eta_{i, t}, \text { for } i=0 \ldots 9
$$

and $\varepsilon_{\mathrm{t}}, \eta_{\mathrm{i}, \mathrm{t}} \sim$ i.i.d. $\left(0, \sigma_{\varepsilon, \eta_{\mathrm{i}}}^{2}\right)$, for $\mathrm{i}=0 \ldots 9$.

In order to run the Kalman filter we need initial parameter values. The initial parameter values are obtained estimating them by OLS using the entire sample (see also Wells, 1996) ${ }^{4}$. Given these starting values, we can then estimate the parameter values using the Kalman filter. We then employ a general to specific approach to obtain a final specification for (2.2), eliminating insignificant lags using the strategy specified in the next paragraph below. The maximum number of lags was determined by the Akaike Criterion (AIC), and was found to be nine in each case. Each time we ran a new regression we used a new set of initial parameter values. Then, for each regression we applied a set of diagnostic tests, shown in the tables in the Appendix, to confirm the final specification found. The final parameter values are therefore filtered estimates, independent of their start values.

Using the specification above implies that we get a set of parameter values for each point in time. Hence, a particular parameter could be significant for all points in time; or at some periods but not others; or it might never be significant. These parameter changes are at the heart of this paper as they imply changes in the lag structure and hence changes in the spectral results. We therefore employed the following testing strategy: if a particular lag was

\footnotetext{
${ }^{4}$ Using the entire sample implies that we neglect possible structural breaks. The initial estimates might therefore be biased. The Kalman filter however corrects for this bias since, as Wells (1996) shows, the Kalman filter will converge to the true parameter values independently of the initial values. And choosing initial values which are "close" to the true values accelerates this convergence. Hence we employ an OLS estimate to start this process; and our start values have no effect on the parameter estimates by the time we get to 1990. Our results are robust.
} 
never significant then this lag was dropped from the equation and the model estimated again. If the AIC criterion was less than before, then that lag was excluded altogether. If a parameter was significant for some periods but not others, it was kept in the equation with a parameter value of zero for those periods in which it was insignificant. This strategy minimised the AIC criterion, and leads to a parsimonious specification. Finally, we tested the residuals in each regression for auto-correlation and heteroscedasticity.

The final specification (2.2) - (2.3) was then validated using two different stability tests. Both tests check for the same null hypothesis (in our case a stable AR(9) specification) against differing temporal instabilities. The first is the fluctuations test of Ploberger et al. (1989), which detects discrete breaks at any point in time in the coefficients of a (possibly dynamic) regression. The second test is due to LaMotte and McWorther (1978), and is designed specifically to detect random parameter variation of a specific unit root form (our specification). We found that the random walk hypothesis for the parameters was justified for each country (results available on request). Finally we chose the fluctuations test for detecting structural breaks because the Kalman filter allows structural breaks at any point and the fluctuations test is able to accommodate this. ${ }^{5}$ Thus, and in contrast to other tests, the fluctuations test is not restricted to any pre-specified (and hence untested) number of breaks. ${ }^{6}$

Once this regression is done, it gives us a time-varying AR(p) model. From this AR(p) we can then calculate the short-time Fourier transform as outlined below, and as originally suggested by Gabor (1946), in order to calculate the associated time-varying spectrum.

\subsection{Spectral Analysis}

As a first step we analyse the power spectral density function of the individual countries. The power spectral density function (PSD) shows the strength of the variations (energy) of a time series at each frequency of oscillation. In other words, it decomposes the

\footnotetext{
${ }^{5}$ Note that all our tests of significance, and significant differences in parameters, are being conducted in the time domain, before transferring to the frequency domain. This is because no statistical tests exist for calculated spectra (the data transformations are nonlinear and involve complex arithmetic). Stability tests are important here because our spectra are sensitive to changes in the underlying parameters. But, given the extensive stability and specification tests conducted, we know there is no reason to switch to another model that fails to pass those tests. ${ }^{6}$ The fluctuations test works as follows: one parameter value is taken as the reference value, e.g. the last value of the sample. All other observations are now tested whether they significantly differ from that value. In order to do so, Ploberger et al. (1989) have provided critical values which we have used in the figures (horizontal line). If the test value is above the critical value then we have a structural break, i.e. the parameters differ significantly from their reference values and vice versa. For reasons of limited space we have excluded the test diagrams from this paper, but report on the results. The diagrams are available from the authors upon request.
} 
variance of a time series into its periodicities. In a diagram it shows at which frequencies variations are strong/powerful, and at which frequencies the variations are weak (expressed in "energy"). The unit of measurement in the PSD is energy (variance) per frequency, frequency band or cycle length. For example, if a time series $X_{t}=\varepsilon_{t}$, where $\varepsilon_{t} \sim$ i.i.d. $\left(0, \sigma^{2}\right)$ and constant over time, the power spectrum would look like the following figure:

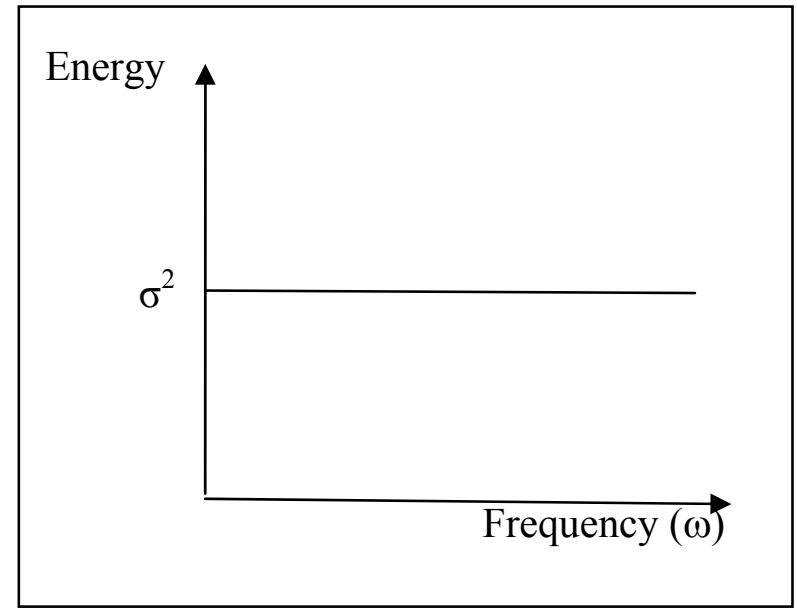

Figure 1: Power Spectrum of a White Noise Process

As one can see from Figure 1, a white noise process is characterised by the fact that no specific frequency has a bigger impact than any other frequency, for $\omega=0, \ldots, \pi$. Given that the level of GDP is often supposed to be integrated of order one, the spectrum of a differenced GDP variable should look rather like figure 1. However, if the data were dominated by long cycles or business cycles, then the diagram would have higher power (variances) at the low or middle frequency bands respectively; and lower power at the high frequencies. ${ }^{7}$

In order to calculate the spectrum from an estimated representation of (2.2), we use the Fast Fourier Transform. The Fast Fourier Transform is an efficient algorithm for computing a discrete Fourier transformation, or in our case a Discrete Time Fourier Transform (DTFT) for discrete points in time. In our case it creates a frequency domain representation of the original time domain representation of the data: eqn (2.2). Hence, our analysis of the spectra and coherences that follow are based on a regression done in the time domain, but then transformed into a frequency domain function by the Fourier transform. However, in this paper we also allow the coefficients of our regressions to vary over time. Therefore we derive

\footnotetext{
${ }^{7}$ In the spectral diagrams that follow, we use the term "power" rather than "energy" to denote relative variances.
} 
one DTFT for each point in time. These calculations define a sequence of short time Fourier transformations (STFT). In discrete time, this means the data to be transformed has been broken up into frames (which usually overlap each other). Each frame is then Fourier transformed, and the (complex) result added to a matrix which records its magnitude, phase and frequency at each point in time. This can be expressed as:

$$
\operatorname{STFT}\{x[n]\} \equiv X(m, \omega)=\sum_{n=-\infty}^{\infty} x[n] w[n-m] e^{-j \omega n}
$$

In this case, $m$ and $n$ are different points in time; $\omega$ is the frequency and is continuous; and $\mathrm{j}=$ $\sqrt{ }-1$. But in most typical applications the STFT is performed using the Fast Fourier Transform, so all variables are discrete and " $n-m$ " would be the estimation window. In our application the window is not constant, but increasing with each new observation. Moreover, we derive the STFT using Kalman filter estimates of (2.2): see section 2.3 below. The squared magnitude of the STFT then yields the spectrogram of the function:

$$
\operatorname{spectogram}\left\{x_{t}\right\} \equiv|X(\tau, \omega)|^{2}
$$

The remaining question is what algorithm do we use to calculate the Fast Fourier Transform? One algorithm often used to calculate the Fast Fourier Transform is the Bluestein algorithm (Bluestein, 1968), which is also called the chirp z-transform algorithm. In particular, it can compute any transform of the form:

$$
X_{k}=\sum_{n=0}^{N-1} x_{n} z^{n k}, \text { where } k=0, \ldots, M-1
$$

for an arbitrary complex number $z$ and for differing numbers $N$ and $M$ of inputs and outputs (see also: Rabiner et al., 1969). Hence, the algorithm we apply to calculate the Fast Fourier Transform is a well-established algorithm and widely used in engineering (Boashash, 2003; Boashash and Reilly, 1992). It is not commonly used in economics however.

Finally Boashash and Reilly (1992) have shown that, once eq. (2.2) has been estimated, its coefficients $\alpha_{i, t}$ can be used to calculate the short time Fourier Transform and the power spectra directly (by applying the Bluestein algorithm). That has the convenient property that the traditional formulae for the PSD are still valid and may still be used, but they have to be recalculated at each point in time. The time-varying spectrum of the growth rate series can therefore be calculated as follows (see also: Lin, 1997): 


$$
\mathrm{P}_{\mathrm{t}}(\omega)=\frac{\sigma^{2}}{\left|1+\sum_{\mathrm{i}=1}^{9} \alpha_{i, t} \exp (-j \omega i)\right|_{t}^{2}}
$$

where $\omega$ is angular frequency and $\mathrm{j}$ is a complex number. The main advantage of this method is that, at any point in time, a power spectrum can be calculated instantaneously from the updated parameters of the model. Hence, we are able to generate a power spectrum even if we have a short time series and even if that time series contains structural breaks.

Thus, when we present our empirical results below, they are based on the time-varying STFT calculations. The only difference from figure 1 is that we have to add a time dimension to show how the spectra have changed over time. The result is then a 3-dimensional diagram.

\subsection{Cross-Spectral Analysis}

In this paper we also investigate the linkage between different business cycles. In the frequency domain, the natural tool to do that is the coherence. The spectral coherence $\left(K_{X Y}^{2}\right)$ is a statistic that can be used to examine the relation between two signals or data sets. Values of the coherence will always satisfy $0 \leq K_{X Y}^{2} \leq 1$. For a strictly proportional linear system with a single input $\mathrm{x}_{\mathrm{t}}$ and single output $\mathrm{y}_{\mathrm{t}}$, the coherence will equal one. If $\mathrm{x}_{\mathrm{t}}$ and $\mathrm{y}_{\mathrm{t}}$ are completely unrelated then the coherence will be zero. If $K_{X Y}^{2}$ is less than one but greater than zero it is an indication that output $\mathrm{y}_{\mathrm{t}}$ is being produced by input $\mathrm{x}_{\mathrm{t}}$ as well as by other inputs. Hence, the coherence is nothing else than the $\mathrm{R}^{2}$ in the frequency domain. Since we are calculating the coherence using the short time Fourier transform, the coherence may also be time-varying. So we have to extend $K_{X Y}^{2}$ by a time index. For the rest of this paper we will write $K_{X Y, t}^{2}$.

Suppose now we are interested in the relationship between two variables $\left\{\mathrm{y}_{\mathrm{t}}\right\}$ and $\left\{\mathrm{x}_{\mathrm{t}}\right\}$, where $\left\{y_{t}\right\}$ is an Asian growth rate and $\left\{x_{t}\right\}$ is the US growth rate for example. We assume that they are related in the following way:

$$
\mathrm{V}(\mathrm{L})_{\mathrm{t}} \mathrm{y}_{\mathrm{t}}=\mathrm{A}(\mathrm{L})_{\mathrm{t}} \mathrm{x}_{\mathrm{t}}+\mathrm{u}_{\mathrm{t}}, \mathrm{u}_{\mathrm{t}} \sim \text { i.i.d. }\left(0, \sigma^{2}\right)
$$

where $\mathrm{A}(\mathrm{L})_{\mathrm{t}}$ and $\mathrm{V}(\mathrm{L})_{\mathrm{t}}$ are filters, and $\mathrm{L}$ is the lag operator such that $\mathrm{Lz}_{\mathrm{t}}=\mathrm{z}_{\mathrm{t}-1}$. Notice that the lag structure, $A(L)$, is time-varying. That means we need to use a state space model (we use the Kalman filter again) to estimate the implied lag structure. That is 


$$
\begin{aligned}
& \mathrm{v}_{\mathrm{i}, \mathrm{t}}=\mathrm{v}_{\mathrm{i}, \mathrm{t}-1}+\varepsilon_{\mathrm{i}, \mathrm{t}}, \text { for } \mathrm{i}=1, \ldots, \mathrm{p} \text { and } \varepsilon_{\mathrm{i}, \mathrm{t}} \sim\left(0, \sigma_{\varepsilon_{\mathrm{i}}}^{2}\right) \\
& \mathrm{a}_{\mathrm{i}, \mathrm{t}}=\mathrm{a}_{\mathrm{i}, \mathrm{t}-1}+\eta_{\mathrm{i}, \mathrm{t}}, \text { for } \mathrm{i}=0, \ldots, \mathrm{q} \text { and } \eta_{\mathrm{i}, \mathrm{t}} \sim\left(0, \sigma_{\eta_{\mathrm{i}}}^{2}\right)
\end{aligned}
$$

As before, we test for the random walk property using the LaMotte-McWorther test. And for structural breaks, we employ the fluctuations test (Ploberger et al., 1989). Finally, we use our previous general to specific approach to estimate (2.7); starting off with lag lengths of nine and $\mathrm{p}=\mathrm{q}$, and dropping those lags which were never significant (as we did before) ${ }^{8}$

Having estimated the coefficients in (2.8), we can calculate the gain, coherence and cross spectra based on the time-varying spectra just obtained. This allows us to overcome a major difficulty in this kind of analysis: namely that a very large number of observations would usually be necessary to carry out the necessary frequency analysis by direct estimation. That would be a particular problem in the case of structural breaks, since the sub-samples would typically be too small to allow the associated spectra to be estimated directly.

In Hughes Hallett and Richter $(2002 ; 2003 a ; 2003 b ; 2004)$ we use the fact that the time-varying cross spectrum, $\mathrm{f}_{\mathrm{YX}}(\omega)_{\mathrm{t}}$, using the STFT can be written as:

$$
\mathrm{f}_{\mathrm{YX}}(\omega)_{\mathrm{t}}=|\mathrm{T}(\omega)|_{\mathrm{t}} \mathrm{f}_{\mathrm{XX}}(\omega)_{\mathrm{t}}
$$

where $\mathrm{T}(\omega)_{\mathrm{t}}$ is the transfer or filter function is defined by $(2.7)$ and calculated as follows:

$$
T(\omega)_{t}=\left(\frac{\sum_{b=0}^{q} a_{b, t} \exp (-j \omega b)}{1-\sum_{i=1}^{p} v_{i, t} \exp (-j \omega i)}\right), \text { for } t=1, \ldots, T
$$

The last term in (2.9), $f_{X X}(\omega)_{t}$, is the spectrum of predetermined variable. This spectrum may be time varying as well. However, in this paper we are interested in the coherence and in the composition of the changes to that coherence over time. So we need to establish expressions for the coherence and gain between $x_{t}$ and $y_{t}$ to show the degree of association and size of impact of $\mathrm{x}_{\mathrm{t}}$ on $\mathrm{y}_{\mathrm{t}}$. The spectrum of any dependent variable is defined as (Jenkins and Watts, 1968; Laven and Shi, 1993; Nerlove et al., 1995; Wolters, 1980):

\footnotetext{
${ }^{8}$ The symmetry in the lag structure, and general to specific testing, allows the data to determine the direction of causality in these regressions. We do not report any results for the reverse causalities that were not accepted.
} 


$$
f_{Y Y}(\omega)_{t}=\left|T(\omega)_{t}\right|^{2} f_{X X}(\omega)_{t}+f_{v v}(\omega)_{t}
$$

From (2.6) we get the time varying residual spectrum

$$
f_{v v}(\omega)_{t}=\frac{f_{u u}(\omega)_{t}}{\left|1-\sum_{i=1}^{p} v_{i, t} \exp (-j \omega i)\right|^{2}}
$$

and the gain as $A(\omega)_{t}=\left|T(\omega)_{t}\right|^{2}$. Finally, given knowledge of $f_{Y Y}(\omega)_{t},\left|T(\omega)_{t}\right|^{2}$, and $f_{X X}(\omega)_{t}$, we can calculate the coherence at each frequency as:

$$
K_{Y X, t}^{2}=\frac{1}{\left\{1+f_{V V}(\omega)_{t} /\left(\left|T(\omega)_{t}\right|^{2} f_{X X}(\omega)_{t}\right)\right\}}
$$

The coherence is equivalent to the $\mathrm{R}^{2}$ statistic, and the gain the regression coefficient, impact or transmission effect of $x_{t}$ on $y_{t}$, in the time domain. Thus the coherence measures, for each frequency, the degree of fit between $\mathrm{x}_{\mathrm{t}}$ and $\mathrm{y}_{\mathrm{t}}$ : equivalently the $\mathrm{R}^{2}$ between each of the corresponding cycles in $\mathrm{x}_{\mathrm{t}}$ and $\mathrm{y}_{\mathrm{t}}$. Hence $A(\omega)_{\mathrm{t}}$ and $K_{Y X, t}^{2}$ measure the link between two variables at time t. For example, if the coherence has a value of 0.6 at frequency 1.2, then it means that country X's business cycle at frequency of 1.2 determines country Y's business cycle at that point in time by $60 \%$. Similarly a gain of 0.5 means that half the variance in country X's cycle at that frequency is transmitted to Y's business cycle. Neither the gain, nor the coherence take into account shifts in the business cycle: such as the US business cycle leads the Chinese one by 1 quarter. In this paper, we are concerned with the coherence and gain, not with measuring the phase shift elements as such. But we are able to detect changes in phase relationships from changes in the relative importance of different cycles in the cross-spectral components.

Last, but not least, a note on the figures shown with the empirical results in the next two sections. We first present the time-varying spectra and then the coherences and gains. One can see from these figures that the spectra change. However, one cannot infer directly from those figures that the changes in the spectra are also statistically significant. The figures for the time-varying spectra/cross-spectra have to be accompanied by the fluctuation test results. Once a structural break has been identified by the fluctuations test, the results will show up as a significant change in the associated spectrum or coherence or gain. 


\section{Empirical Results: Single Spectra}

In this section and the next, we study the spectra and cross-spectra of output growth in selected Asian economies compared to the US, or compared to China, over the past 20 years. We take the US and China to be the potential leading economies ("economies of first resort") in the Asia-Pacific area and analyse the changing relations between them, and between them and China's special region economies (Hong Kong and Taiwan), since the Asian financial crisis in 1996-7. Similar results for the changing relationships between the US and the UK, and the US vs. the Euro-zone, will be found in Hughes Hallett and Richter (2006) and can be taken as a benchmark for these comparisons. Further comparisons are made with two parttime members of the emerging Chinese economic area (Singapore, Malaysia) in order to provide a standard of comparison (or unit of measurement) for our analysis.

For all countries we use the IMF International Financial Statistics data base. All GDP observations are quarterly data, already deflated by the IMF statistical service and expressed in US dollars. They are also seasonally adjusted by the IMF. Finally, we log difference the GDP data which results in the (quarterly) growth rate. We use seasonally adjusted quarterly data from 1987:4 to 2006:3. The sample starts earlier for Hong Kong (1977), Taiwan (1984), and the US (1982), but later for Malaysia (1990). The analysis will therefore be restricted to the period following the stock-market and financial crash of 1987 . The Taiwanese data is taken from the Taiwan national statistical service publications.

The resulting data are then fitted to an $\operatorname{AR}(p)$ or $\operatorname{ADL}(p, q)$ model as described above, and tested for stationarity, statistical significance, and a battery of diagnostic and specification checks before being converted to the spectra and cross-spectra that we need. The time domain regression results and tests are set out in detail in the appendix to this paper.

a) The Core Economies: the US and China. One striking feature of the individual country spectra is that, in both core economies, the trend growth rate does not play an important role in terms of spectral mass. Indeed, taking into account the vertical scale in each diagram, there is very little volatility in output growth of any kind in China after 1987 (figure 3), except at the business cycle frequency, and only then until the period of especially rapid trade growth and trade surpluses from 2004 onwards. This is in stark contrast to the US spectrum (figure 2) which shows the declining power of trend growth after 1987, and mildly increasing volatilities at short or short-to-medium cycle lengths over the same period. There is a clear persistence in her trend growth rates nonetheless. 


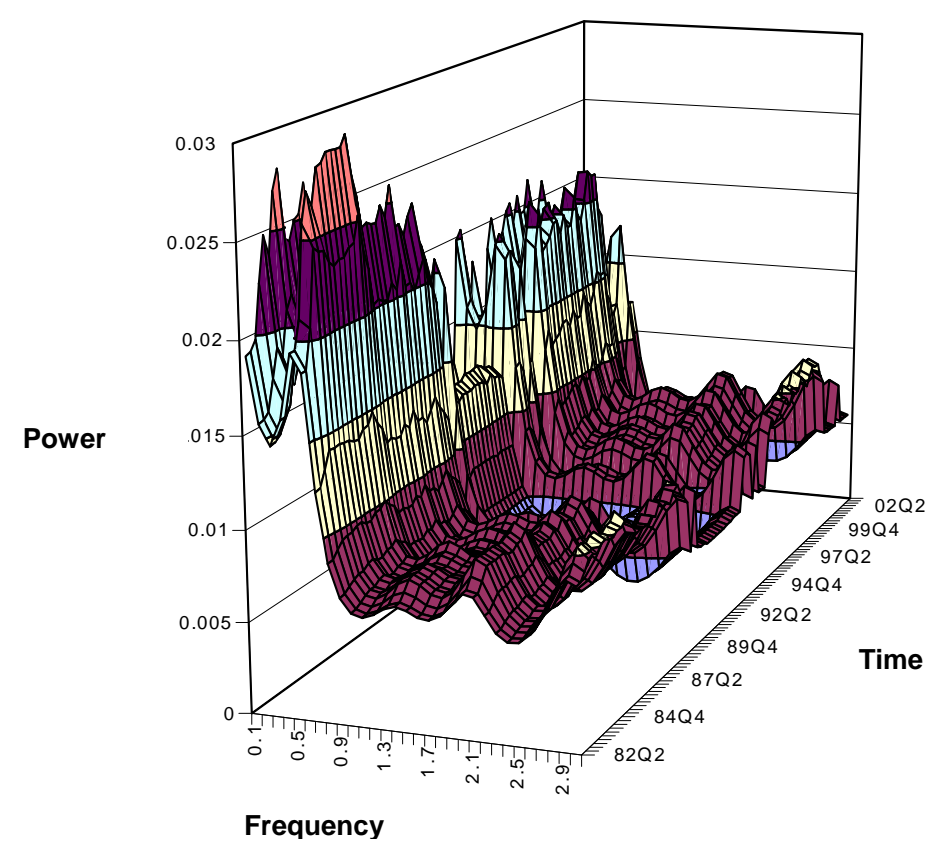

Figure 2: Spectrum of the US Growth Rate

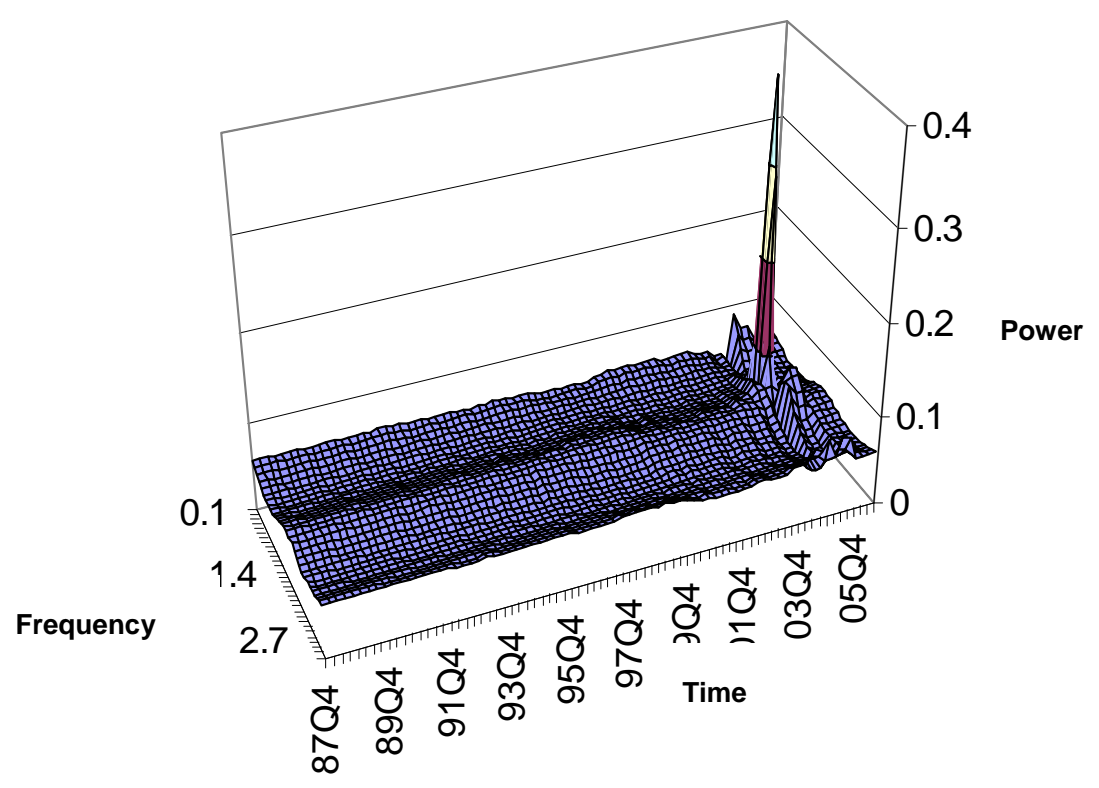

Figure 3: Spectrum of the Chinese Growth Rate

In making these points, we are drawing a clear distinction between persistent trends, meaning events whose effects on performance last a long time before dying away or being over-taken by subsequent events/changes; and constant growth trends whose effects are persistent and always the same in terms of economic performance. Obviously the former implies some 
variance in the outcomes, if only slowly changing, and hence some long cycle power in the associated spectrum. But the latter implies no effective variance in the outcomes, and hence no power in the corresponding spectrum at low frequencies (or anywhere else).

There may therefore have been change in these economies; but it is not a change that has altered the pattern of growth in the US in any significant way, or the growth patterns in China for that matter, except in the period after 2003. That is not to say that the relationship between these two economies has not changed. But if it has, it must have been a change involving others outside the region; or, more likely, a change that involved a reallocation of roles between the economies of the Asia-Pacific area, rather than a change in their behaviour or their dependency as such. The latter appears more likely because the pattern of structural (regime) breaks shows little in common taking each economy separately. Had they been settling into a new regime, there would have been something in common in the structural breaks as each economy entered that regime. As it is, the US is only showing structural breaks in 1996 and 2001 (the Clinton-Greenspan boom); while China shows a series of small breaks in 1993, 1995 (the start and finish of the high inflation period), 1999-2000 and 2002 (the onset and end of deflation), and then a very large one in 2004-5 (expansion of trade, curtailing of Chinese imports). With a pattern like that, these breaks are far more likely to reflect changes in the domestic economies than in the trade or financial links between them.

b) The Special Region Economies. The spectrum for Hong Kong (figure 4) is quite different

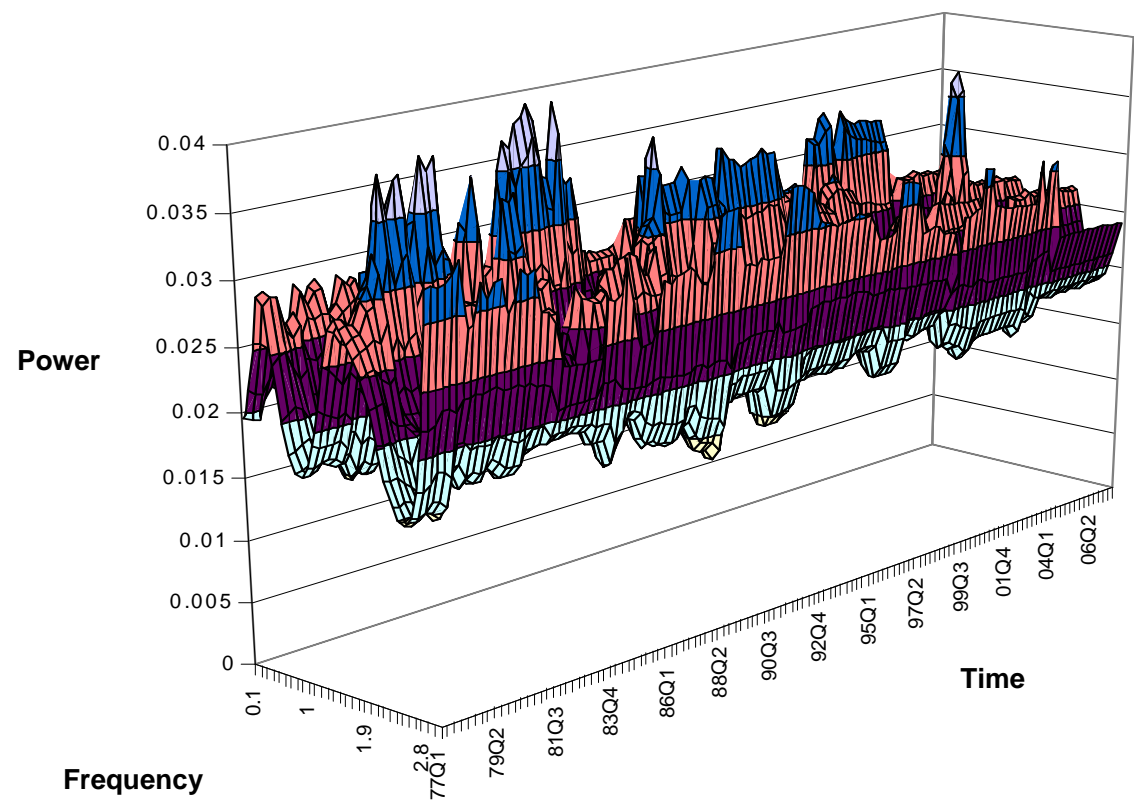

Figure 4: The Spectrum of Hong Kong 


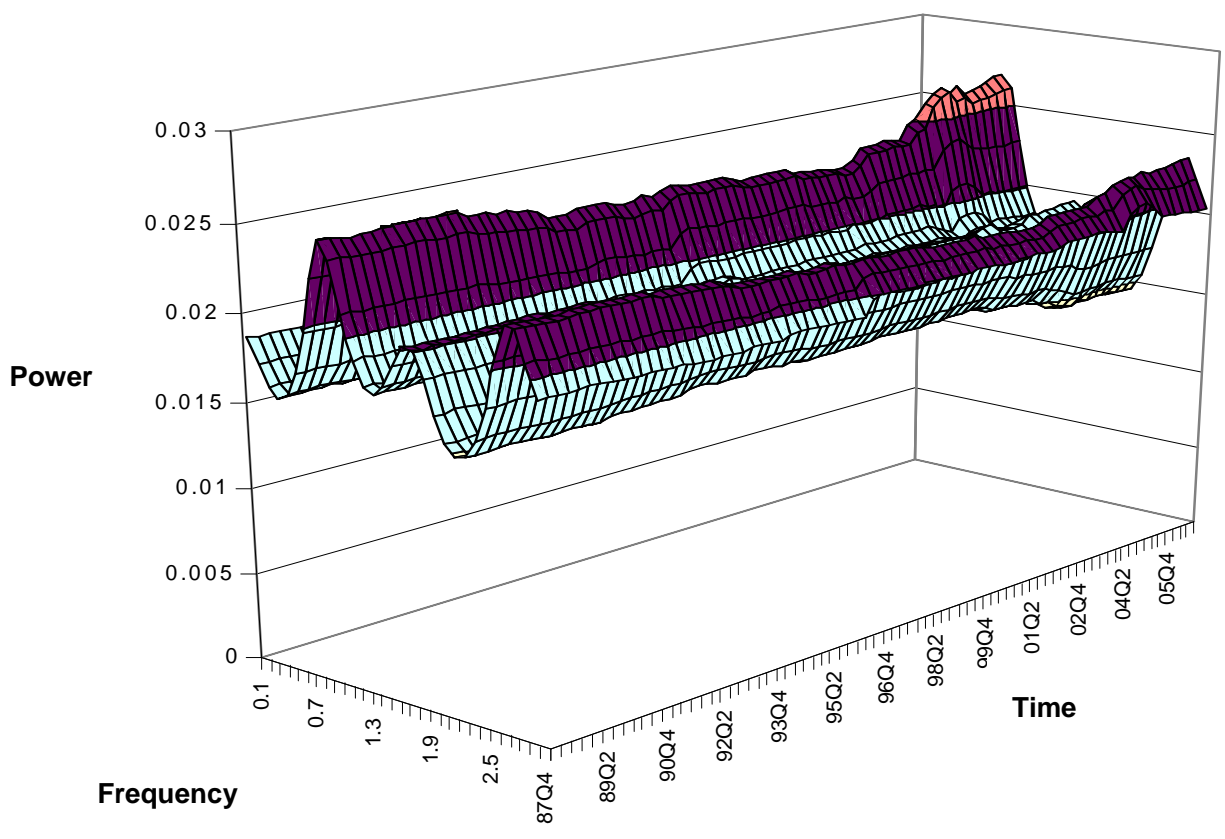

Figure 5: Spectrum of the Singapore Growth Rate

and has, on the face of it, little in common with China or Taiwan other than the fact that it has rather low power over all frequencies. That power is concentrated at business cycles and the short end of the spectrum; and has been so since the 1980s, strengthening in good times but weakening at others (in the early 1990s, at the hand over in 1997, and since 2004). Singapore (figure 5) likewise shows some volatility in growth, both at long and at short cycles, but no marked tendency for the strength of those cycles to increase or decrease. Singapore has also seen some increase in volatility since 2002 , but it is not large and does not change the pattern of growth.

Malaysia meanwhile (figure 6) is different again in that she has power and hence volatility at the business cycle and short cycle frequencies. But this has not changed since 1996; and there is rather little power at long cycles or trend growth. 


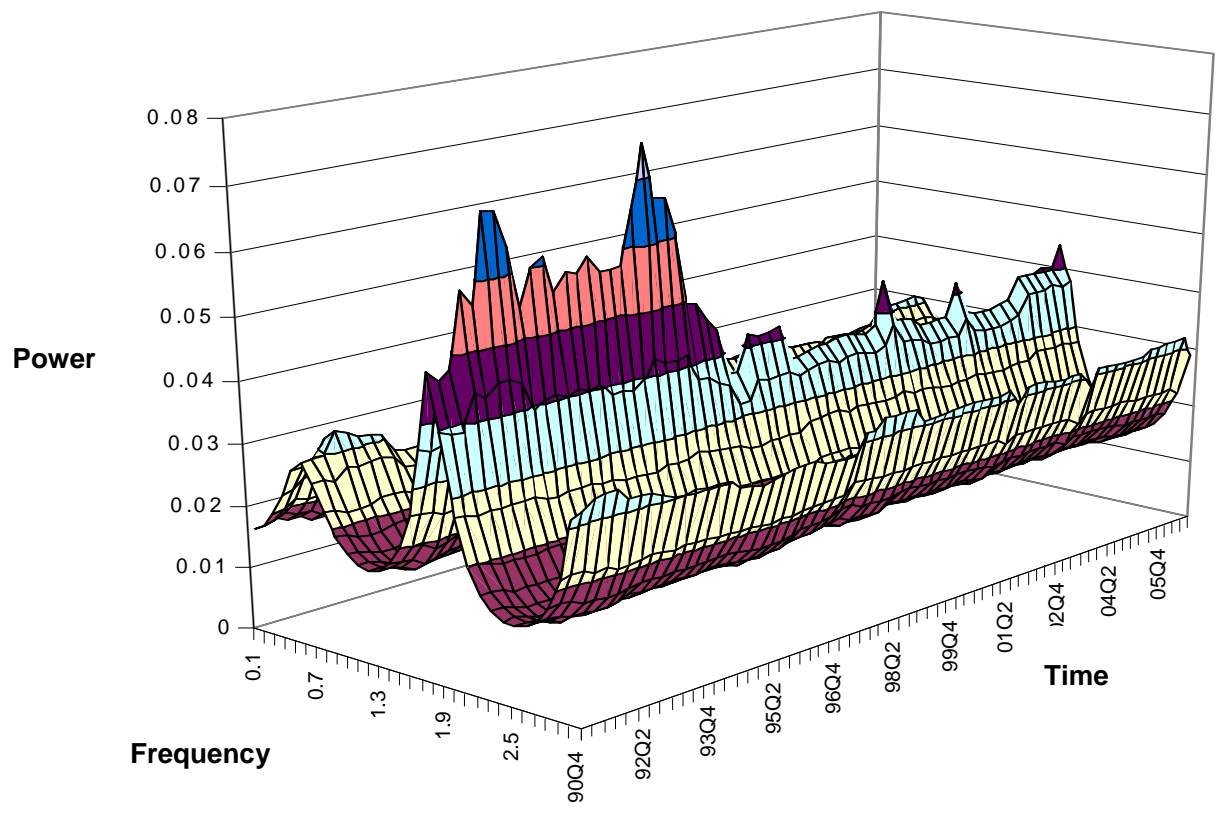

Figure 6: Spectrum of the Malaysian Growth Rate

Taiwan (figure 7), by contrast, is rather similar to China. The Taiwanese spectrum has no power at long cycles or trend growth; and very limited power at business cycle frequencies (with the exception of the spike at that frequency in 2003-5). In that respect the Taiwanese economy is the most similar to the Chinese economy, but with less power at the business and trend growth cycles.

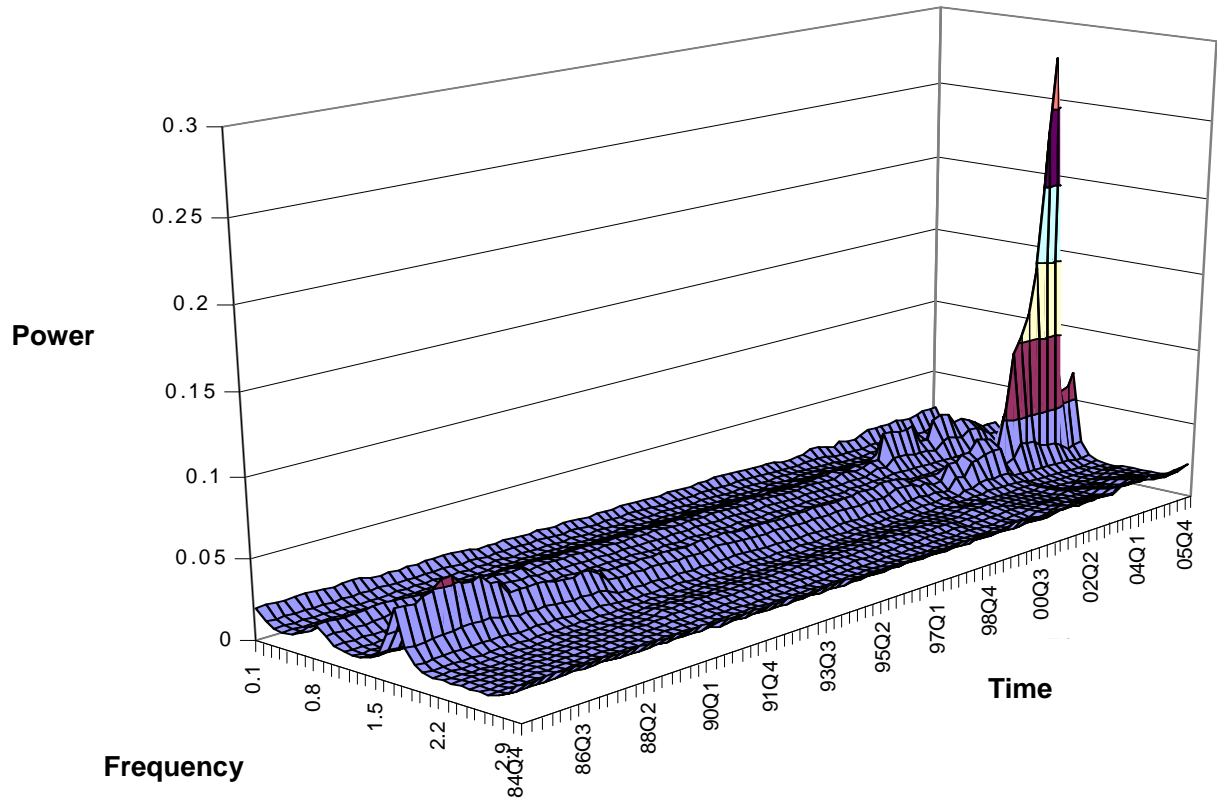

Figure 7: Spectrum of the Taiwanese Growth Rate 
c) Commentary: A working conclusion at this stage is that there has been no great change in the growth patterns of these economies in the past two decades; with the exception of minor increases in volatility at business cycle frequencies at the time of the Asian crisis, and also since 2004 in China, Taiwan, and (possibly) Hong Kong or Singapore. This makes it hard to see if there is an emerging group of economies in the Chinese sphere with common cyclical and economic behaviour. One suspects not. But to establish that, we need to see if the within group coherences and gains have increased; and if those out-of-group (and with the US in particular) have also decreased at the same time. If that were true, it would be consistent with the Demertzis et al. (1998) who found that the core and periphery economies in Europe had more in common with each other than any of them did with those outside their group. Even so, the low spectral power in China area economies shows they are all influenced by similarly stable growth rates. That much they do have in common, in contrast to the US. But it is certainly not a new phenomenon; such similarities have existed since the 1980s.

\section{Increasing Coherence: China and the Special Regions?}

We now turn to the coherence, or correlations, between the economic cycles of our economies at different frequencies, and whether those coherences have increased or decreased over time. These results supply, first, a test of the hypothesis that the Chinese economies form a coherent group, more similar in their performance than with those outside the area, and could therefore be regarded as an emerging single economy. Second, it will show if their dependence on the US has decreased as the strength of the linkages between those in the China group has increased. Third, we can test the argument that, if exchange rates are pegged, then business cycles will converge as trade and financial links intensify. This is an important matter. Artis and Zhang (1997), Prassad (1999), and Frankel and Rose (1998, 2002) have argued that this will happen as trade and financial links strengthen. However, Kalemli-Ozcan et al (2001, 2003), Hughes Hallett and Piscitelli (2002), Baxter and Kouparitsas (2005), Peersman and Smets (2005) show that it does not always happen in theory or practice, and it may not happen in this case. The advantage of our approach is that we have a ready-made control group: China-Hong Kong-US have maintained (mostly) fixed exchange rates over the sample period; but Taiwan has had flexible rates. We can examine this hypothesis directly therefore, and attribute the results to the exchange rate arrangements rather than to increased 
trade and financial flows. If the convergence is in Taiwan, not Hong Kong, then fixed exchange rates are not sufficient.

This section provides empirical evidence on these three hypotheses, with the addition that we can show the frequencies at which any increased spillovers occur. This is an important step because spillovers may occur at certain frequencies and not others, implying that average correlations could appear to increase when the vital linkages at the business cycle frequency have decreased (or vice versa). We are primarily interested in coherence at business cycle frequencies because of what it implies will be demanded of the policy makers; and of price and wage flexibility in particular. But short and long cycle coherences are important too, for their ability to transmit persistent or short term shocks, and whether the volatility transmitted by these linkages is short or long term in its effect.

\section{a) Coherence among the two leaders: the US and China.}

We first examine the coherence and gains, that is the cyclical association and spillover effects between the two largest economies in the Asia-Pacific region (figure 8). From the China-US relationship ("US affects China"), we see that the coherence has been declining gradually from 1987 to 2001; but that it remained at a reasonably high level of 0.4 to 0.5 throughout ${ }^{9}$. However it increased again rather abruptly in 2001 , to imply a stronger if somewhat uncertain influence (there are several interruptions in this increased coherence) of US growth on China at the long, short, and (most of all) at the business cycle frequencies from 2004 to 2006 .

\footnotetext{
${ }^{9}$ Note that each coherence/gains relationship implies a direction of causality, and hence different degrees of association or spillover effects, depending on whether we are looking at how much US growth affects growth in China or how much Chinese growth affects the US performance. We therefore get different results, and different implications, depending on whether the underlying regressions specify Chinese growth to be a function of US growth rates; or US growth as a function of Chinese growth. Coherences can therefore imply that one growth pattern is more closely associated or dependent on another, than holds in reverse (the dependence/association of the second on the first).Coherence therefore measures the generalized closeness of fit between two variables $x$ and $y$, rather than the simple correlation coefficient which is symmetric. Gains likewise measure the impact effects of growth in one economy on another, and therefore vary with the direction in which the linkage is supposed to run.
} 


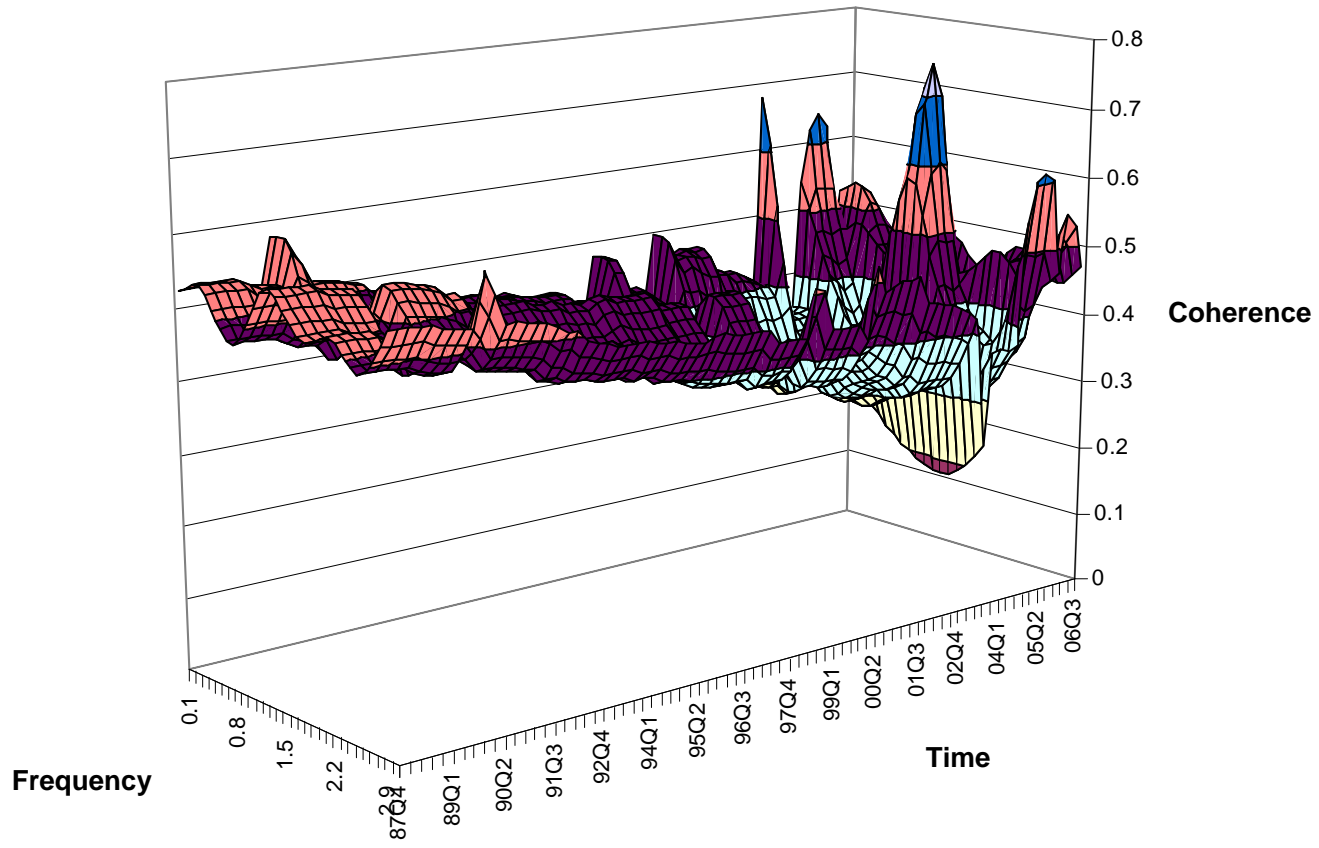

Figure 8: Coherence between China and the US

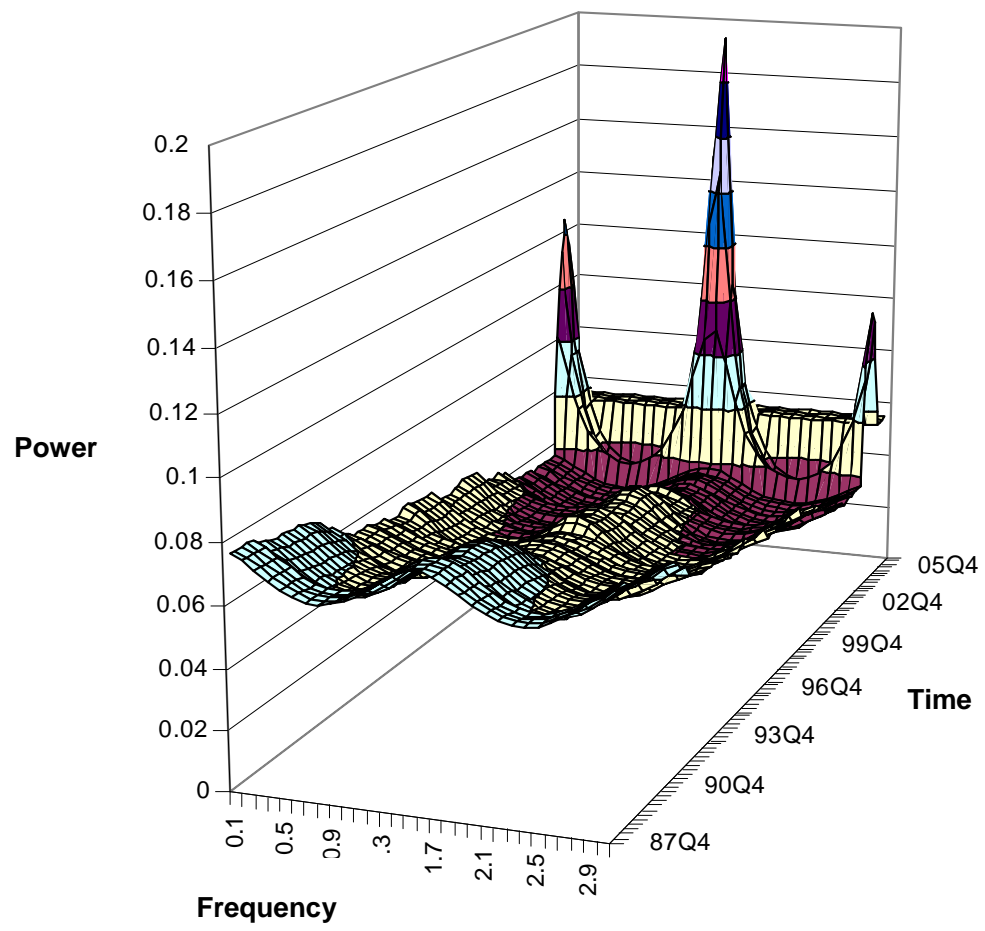

Figure 9: Gain between China and the US

The gains (figure 9) however show that the impact of US growth on the Chinese economy to be quite small, with multipliers of below 0.08 per unit change in the US, and declining until 2002. But then there is a sudden increase in the US influence at short, long and business cycle 
frequencies in 2003-4. So much so that, by 2005, the spillovers onto China had settled back to the levels previously reached in 1990-91. So there is partial support for our first hypothesis, but not quite as expected. US dominance and economy of first resort effects have declined with respect to China as hypothesised, but slowly and only up until 2002. The recent surge in trade with the US, based as it is expanding exports and the substitution of imports in China, has now reversed that decline although the influence of the US on China remains small.

In the light of these results, it is most important to see if the counterpart is true: if China's impact on the US economy has also been increasing. We might expect to see the China to US gains (figure 11) and coherence (figure 10) to be increasing with the expansion of trade and financial flows between the two, in the same way as the US to China coherence and gains increased. To some extent we do. The US-China coherence is rather low, but falls steadily (from 0.1 to 0.05 ) up until 2001 just as the China-US coherence did. It then jumps

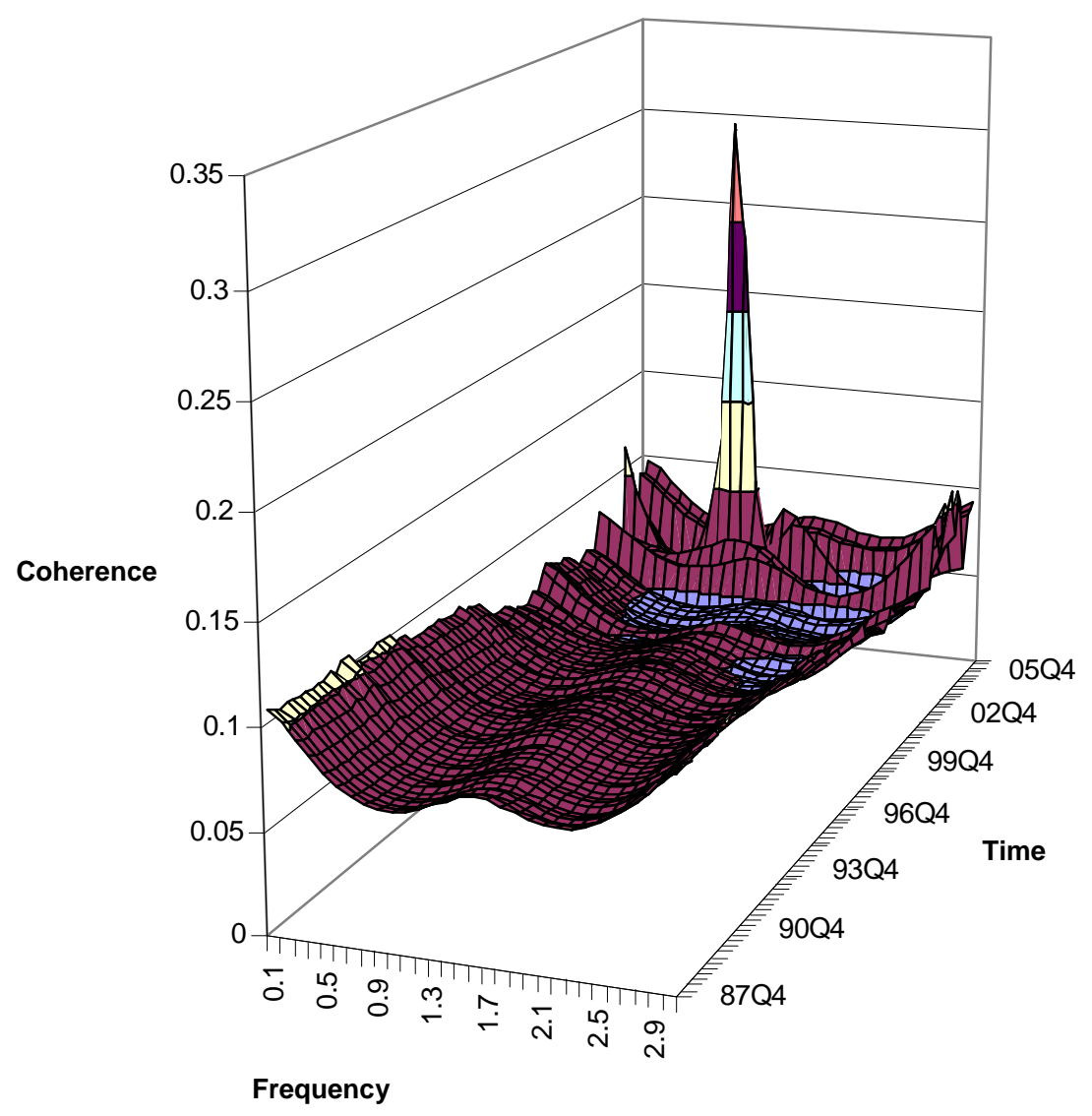

Figure 10: Coherence between US and China 


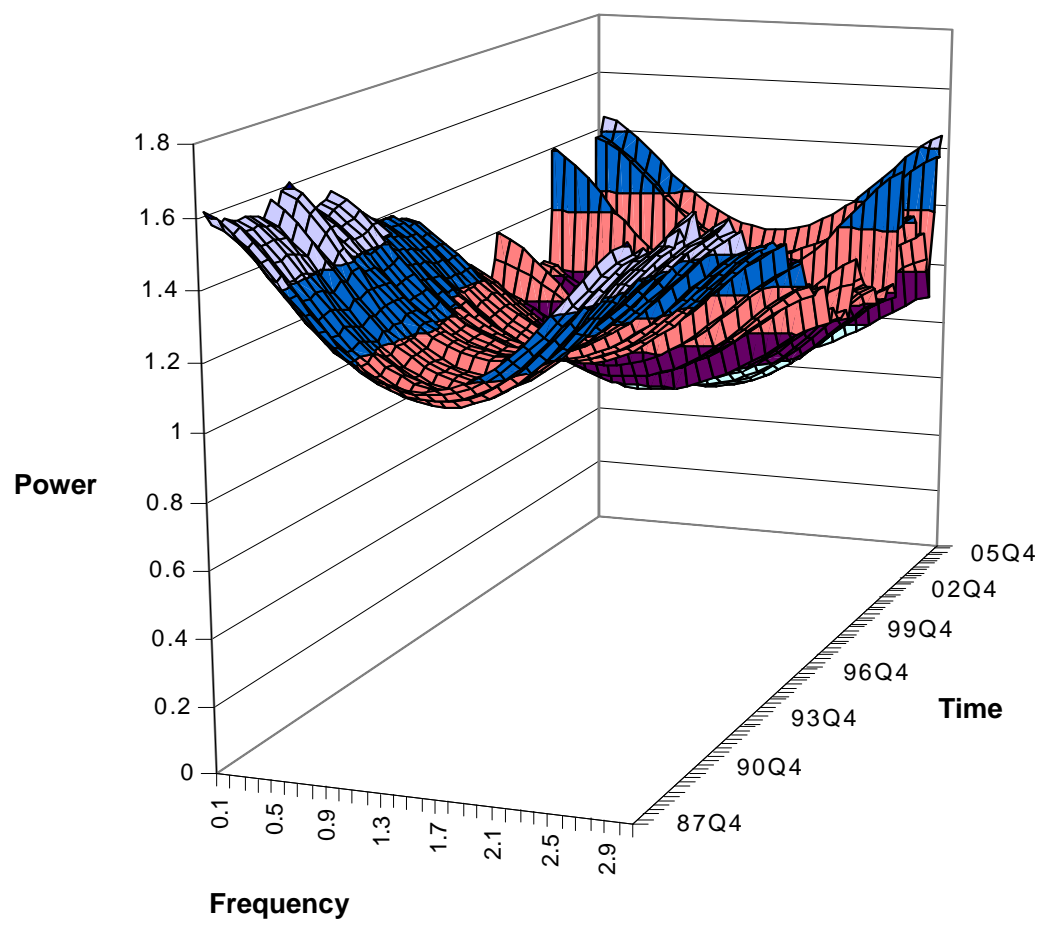

Figure 11: Gain between US and China

back up to 0.1 (and temporarily to 0.3 at the business cycle frequency) and remains, rather uncertainly, at that level. In the same way, the US-China gain (the impact of Chinese growth on the US) is high but falls steadily until 2001, and then recovers sharply to values similar to those of the early 1990s - again similarly to the China-US case, although this has happened more at the long and short cycles than in the business cycles. That suggests a change in the phase relationship. If there were such a change, then the strength of the coherence or gain must increase at some frequency, and decrease at another, while the change itself takes place. Since we are not interested in the size of the leads or lags, only in their changes, we can limit our tests for changing phase shifts (and implied changes in product mix and supply dependence) to such events.

These results might therefore suggest a continuing linkage between China and the US, based on the assumed leadership of the US economy in the 1980s and 1990s. However that inference would be wrong because of the asymmetry in this linkage: the US to China linkage has a high coherence but a low gain, while the China to US linkage has low coherence but a high gain. Such asymmetries give us the pattern of dependency or leadership. In this case, it appears the US has the power to shape the cycle in China through her dominance of monetary (interest rates, supply of capital, exchange rates) and financial conditions; while China has the power to influence spillover effects onto the US (and hence the size of the cycle) through the 
"outsourcing" of manufactures and cheap intermediate inputs for the US economy. This gives a more nuanced view of the relationship between the US and Chinese economies, where they dominate and where they are vulnerable, than is generally assumed. It is consistent with the idea that China has gained greater influence through trade, at the cost of a dependence on foreign monetary conditions (risking inflation, excess liquidity, asset bubbles). However, the point is that this relationship is not new. It has been in this form since the 1980s; although it has become stronger, if more uncertain, since 2000.

\section{b) Coherence between the Special Region Economies and the US.}

Like China, the special region economies (Taiwan, Hong Kong) have experienced some weakening in their linkage to the US since the 1980s. They show low coherences and falling gains from US activity, but coherences and gains that pick up again rapidly in 2000-01 period. Specifically, Taiwan's coherence (figure 12) with the US is low (less than 0.05), falls to zero after 1991, and only revives after 2000 to give modest correlations at the 3-year, 1year and shorter cycle lengths. The associated gains (figure 13) are even smaller, in decline to 1999, and only then increase to values between 0.01 and 0.02 . These changes appear at all frequencies, but with an emphasis at the short and business cycle frequencies.

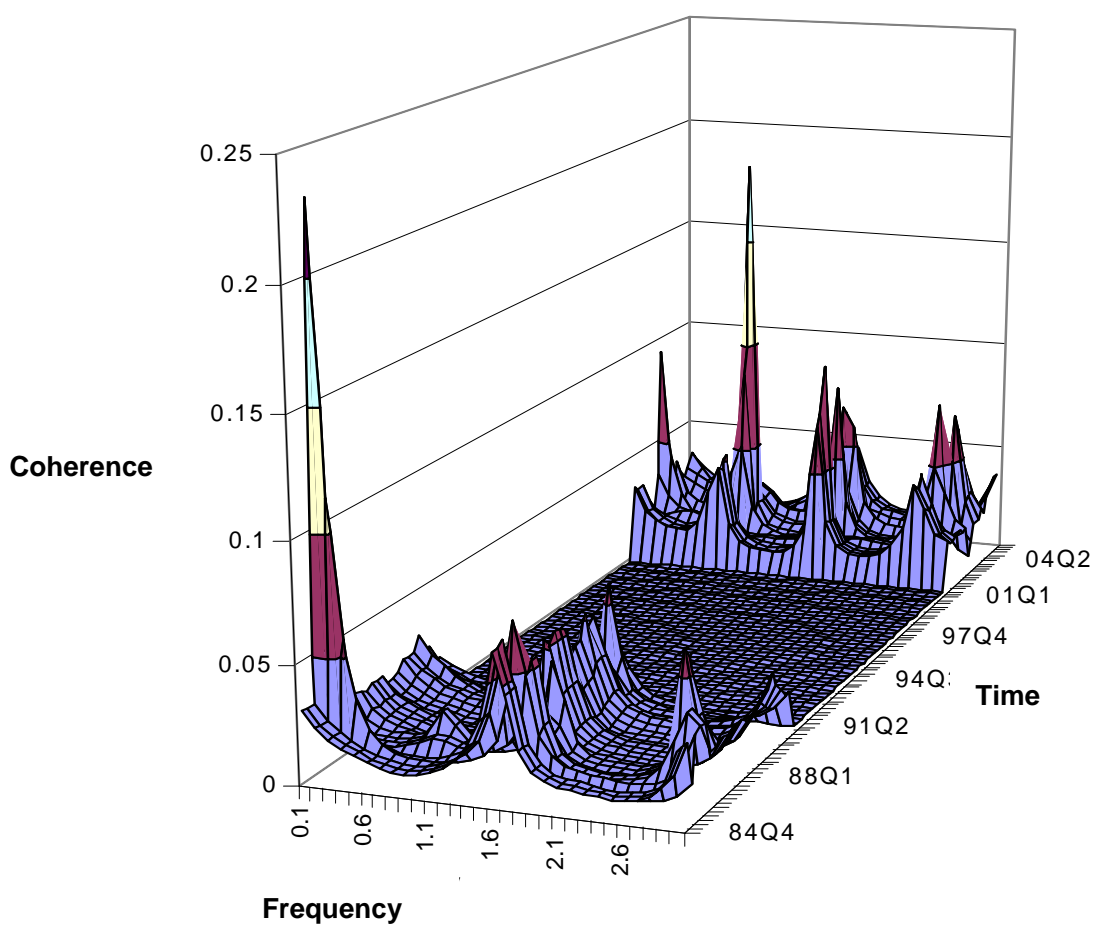

Figure 12: Coherence Taiwan - US 


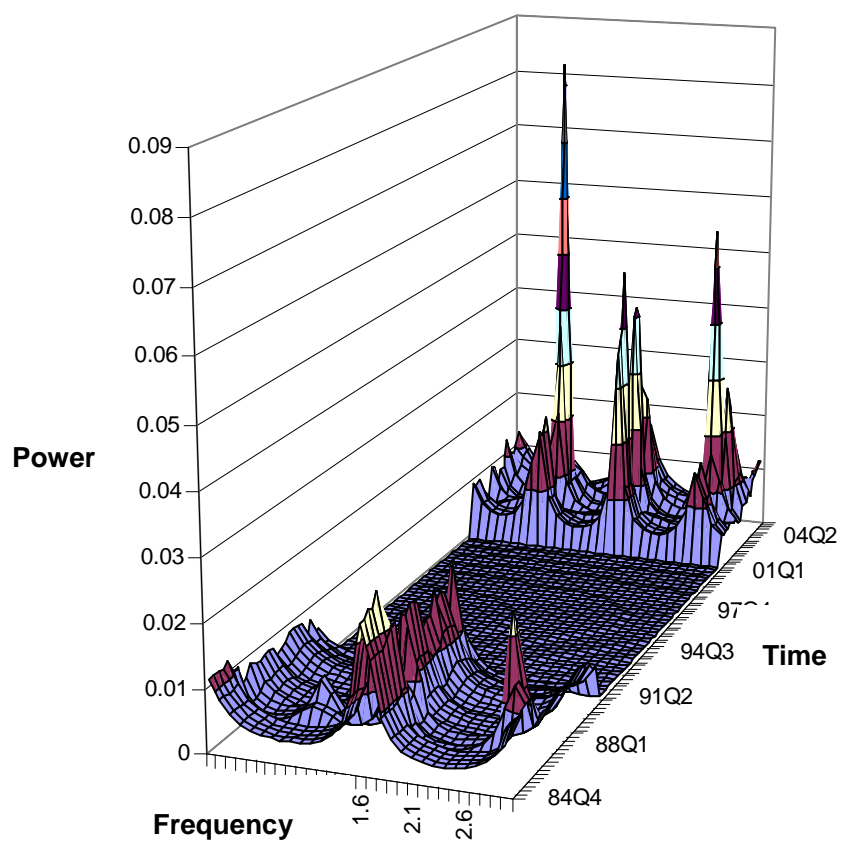

Figure 13: Gain Taiwan - US

Hong Kong's coherence (figure 14) and gains (figure 15) with the US tell a rather different story. The coherences are also low, often zero, but reach 0.06-0.16 in the recessions of $1978-80,1991-92,2002-04$. In those periods the coherence is clearly stronger at short cycles than at business or long cycle frequencies, and that this may be a developing trend. This suggests an economy which is still linked to, or dependent upon, the US at least in bad times - presumably a reflection of her financial and investment links. These are not features that appear in the Taiwan results.

One interesting point to note is that both Hong Kong and Taiwan have periods of zero gains and zero coherences between 1991 and 2001. This is an artefact of the fact that crossspectra are defined as real numbers. Consequently the gains are defined by the absolute value of the (complex) Fourier transform given at equation (2.9), of the coefficients of the underlying time domain ADL relationship (2.7). Hence the gains go to zero if the coefficients in $\mathrm{A}(\mathrm{L})$ all go to zero; meaning, in this case, that the US economy has no further influence on the growth cycles of that particular economy. Moreover, our general to specific specification 


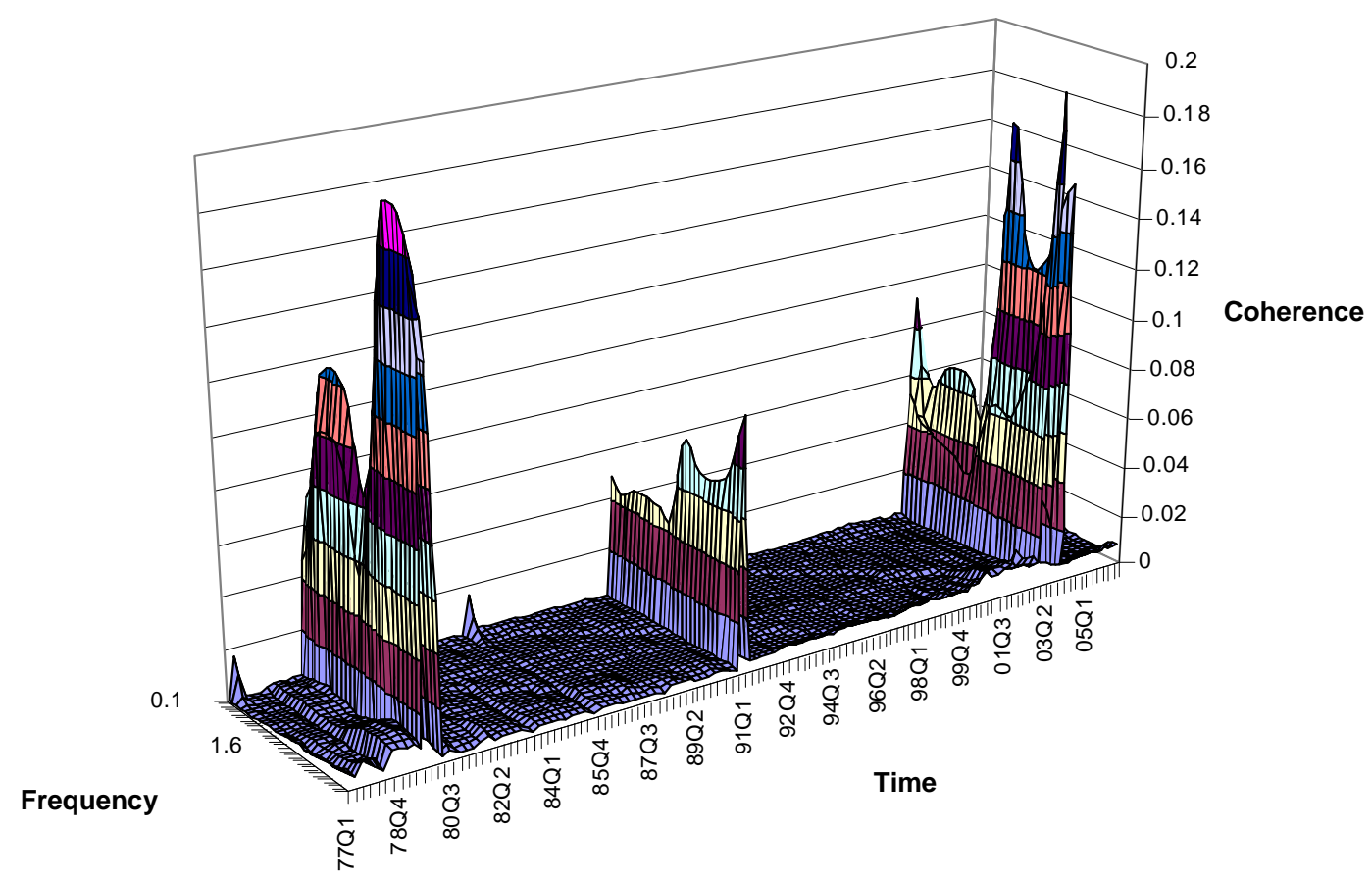

Figure 14: Coherence Hong Kong - USA

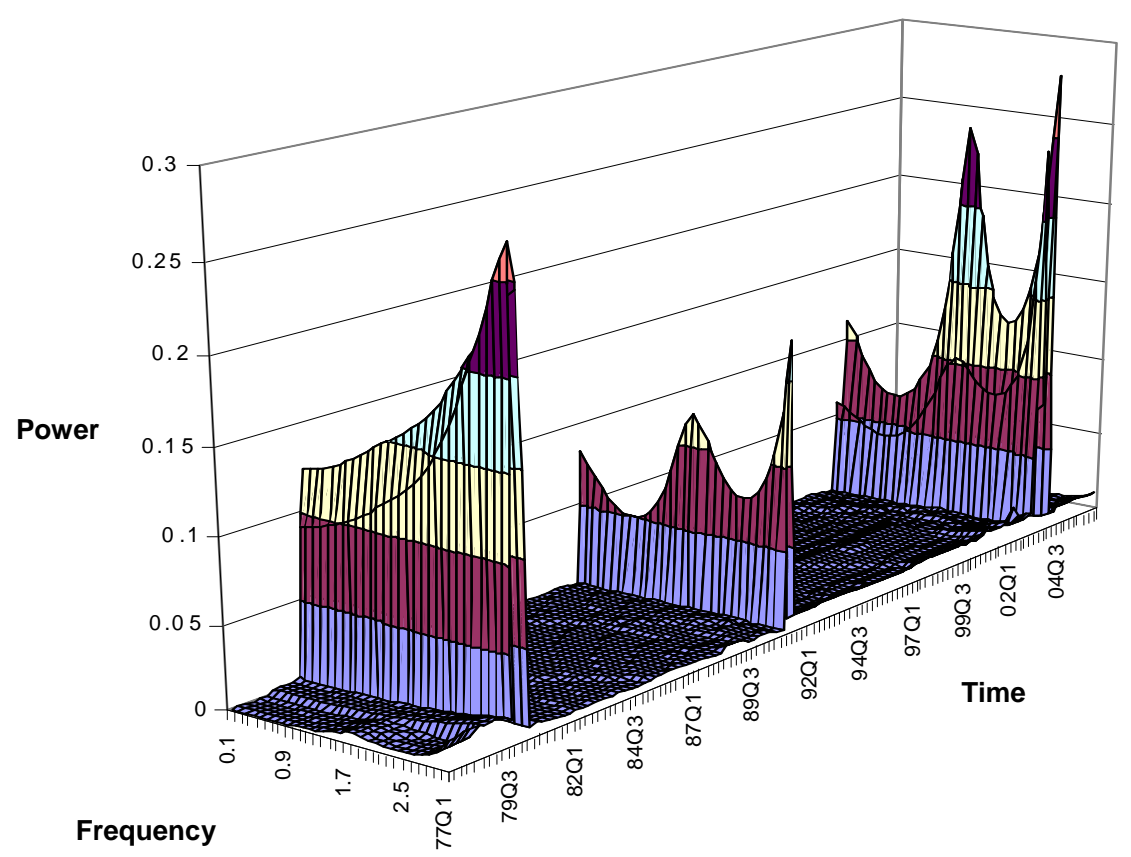

Figure 15: Gains Hong Kong - US

and testing procedures will automatically set those coefficients to zero if they are not statistically significant in a particular period. So a zero gain means that Hong Kong and Taiwan became dissociated from the US economy in those periods. Or, to be more accurate, that the US economy had no significant impact on their growth or cycles. And once $|\mathrm{T}(\omega)|$ 
goes to zero, then so does the corresponding coherence. Since this happens to the Hong KongTaiwan-US relations, but not within the China bloc, and not for the other large trading economies in the region (Japan, Korea, Malaysia) and only intermittently for Singapore, this provides some significant evidence of the emergence of two separate blocs in the Asia-Pacific area (as argued in Hughes Hallett and Richter, 2008).

\section{c) Between the Special Region Economies and China.}

We now review the coherences between China and her two special regions. In both cases we only consider the case where China influences the Hong Kong or Taiwan economies; not the case where China is dependent on Hong Kong or Taiwan for which we could find no significant evidence. ${ }^{10}$

Figure 16 shows the coherence between Hong Kong and China. At the beginning of the sample there is only coherence between the two for the trend cycle and at cycle lengths of 1.1 (6 quarters). But over time, and most obviously after the handover of Hong Kong in 1997, the coherence shows increases at all but the short cycle frequencies (those less than one year in length). Nevertheless those changes are concentrated at the trend or long cycles; and to a lesser extent at business cycle frequencies. Short cycle coherence is absent except at specific dates $(1991,1999,2004,2006)$. This coherence diagram is a good example of convergence, in terms of the coincidence of movement due to longer term investment, trade and the trade in services. But short term income fluctuations, uncertainty/noise effects, and short term financing show little coherence with China except in bad times. These results cannot show which way the fluctuations and short term financing help goes; but the consistently low gains at short and middle cycle frequencies in figure 17 show that the income fluctuations are in fact in China, and the short term financing goes to China. The gains more generally are lower than the Hong Kong-China coherences across all frequencies; at 0.2-0.3 in size except in the post hand-over period, they are one third to one half of the corresponding coherence values and have virtually melted away since 2003 . Nonetheless some frequencies play a special role $(0.8$, 1.5 and 2.9), reflecting the occasional shocks transmitted in 1991, 1998, 2003 and 2005 which explain the peaks in short term coherence noted above. But even these low level gains are declining, and have now been lost (since 2005).

\footnotetext{
${ }^{10}$ They might nevertheless have exerted such an influence, both as a matter of economic size, and as suppliers of certain key services, components or investment. So this point is not as innocent as it might appear.
} 


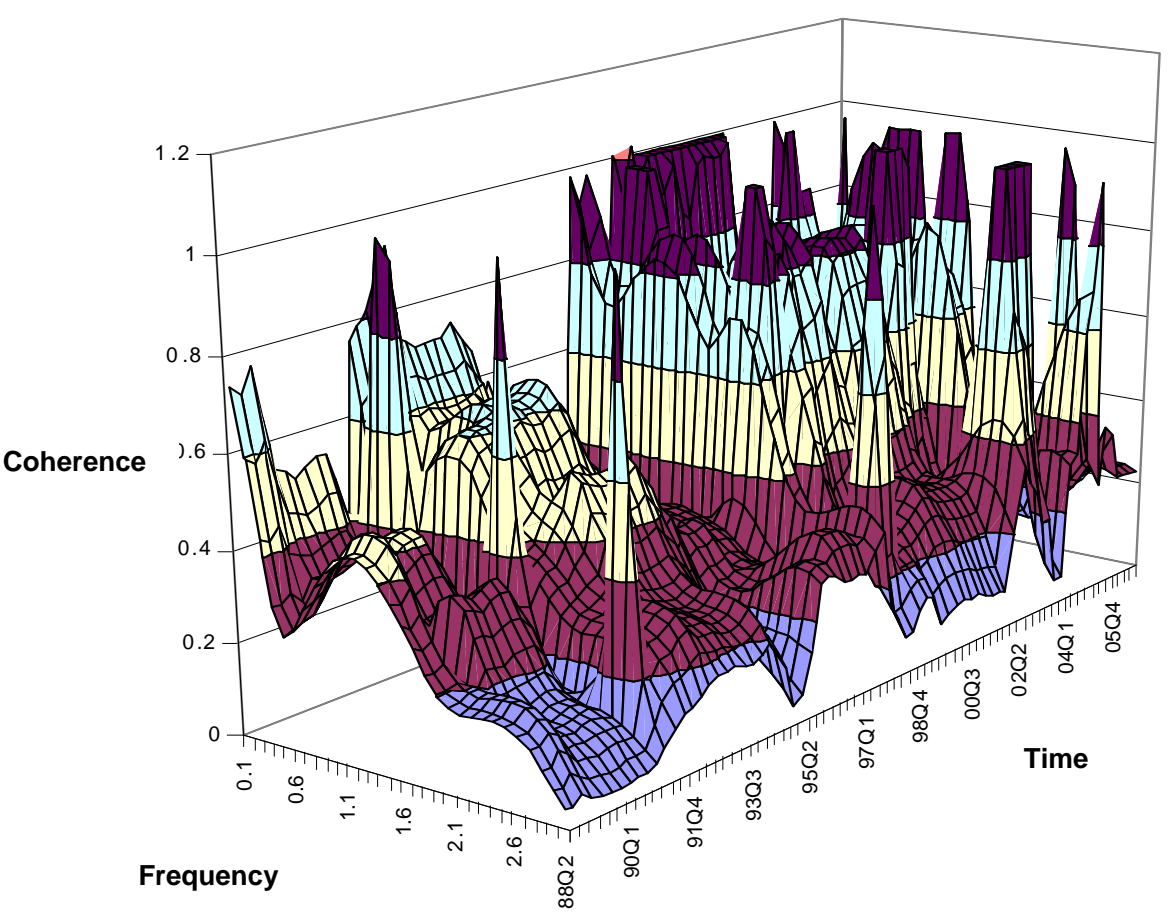

Figure 16: Coherence Hong Kong - China

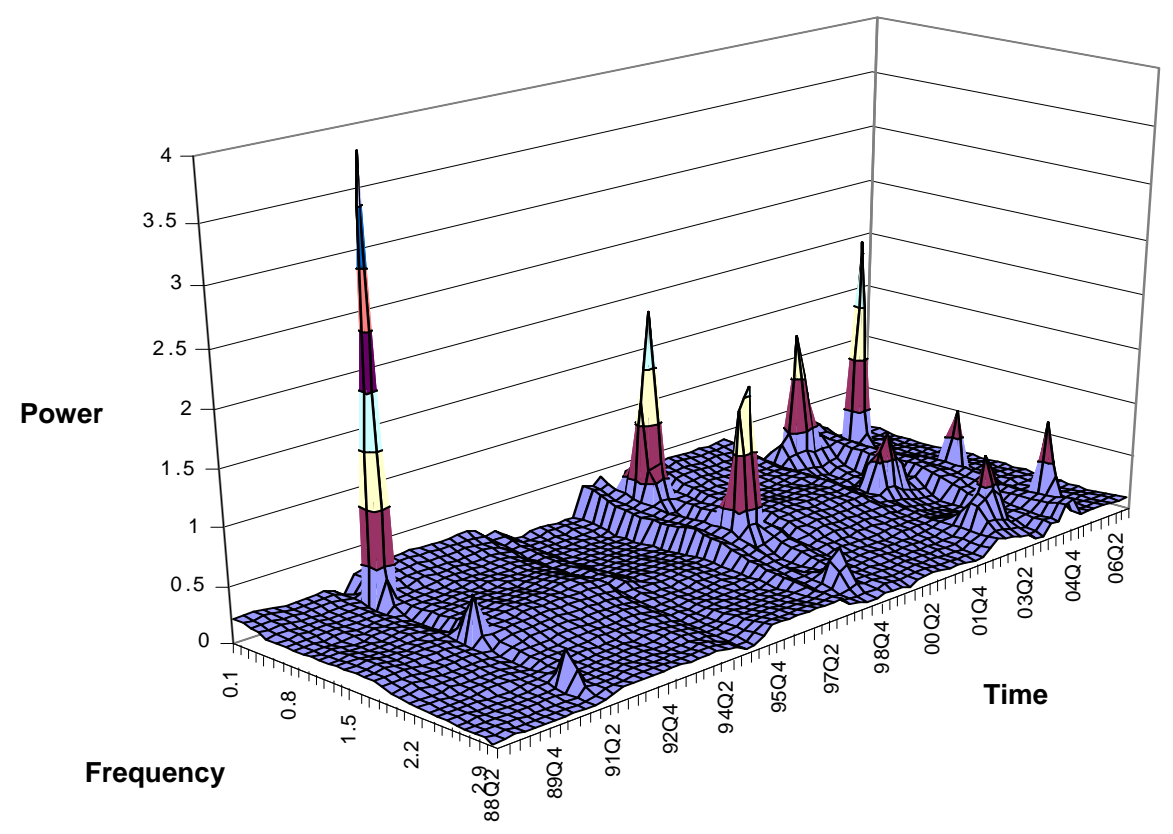

Figure 17: Gains Hong Kong - China

These results have therefore left Hong Kong in the same position, in her Hong KongChina relationship, that China had occupied in the China-US linkage: a large coherence, but small spillover effects. Hong Kong is therefore subject to the existence and shape of a cycle generated in China; but she is able to influence, if not control the size of that cycle herself. 
That shows Hong Kong has developed as an independent economy, well integrated with China but specialised and trading according to comparative advantage as a supplier of services, entrepot trade, investment and short term finance. But she is not an integral part of the Chinese economy as such.

None of these results are available in the Taiwan case where the coherences with, and gains from, China are approaching equal size at the long and business cycle frequencies. In fact Taiwan shows the closest relationship to, and most influence from China. Our TaiwanChina coherence, figure 18 , is substantially higher at 0.4 to 0.5 in 2004 than our other China coherences (including that with the US) or the Korea-Japan coherence in Hughes Hallett and Richter (2008). Moreover there has been a precipitous rise since 2002 (possibly since 1999), with power concentrating at the long and business cycle frequencies and away from the short to intermediate frequencies. That suggests that a shift in phase and in product structure has taken place: with an increase in consumer goods traded both ways and increased intermediate inputs from China to Taiwan affecting business cycle frequencies; and increased financing from Taiwan to provide the long cycle connection. The gains, figure 19, show the same thing for the influence of China on Taiwan. Those gains are not especially large at 0.2-0.3, although they are larger than for other members of the China bloc even after the shifts of 2002.

Nevertheless, the Taiwan-China coherences remain moderate: more than for China influencing the US, but smaller than the US influence on China. The gain effects (China affects Taiwan) are somewhat smaller again at 0.2-0.3, although they too show a clear increase in 1997 at the short and long frequencies, before tailing off again after 2003. This is consistent with Taiwan partly developing separately from China, although one might have expected more linkage between the two as Chinese components are increasingly used, and Chinese manufactures consumed, in Taiwan; and as more Taiwanese equipment and investment goes to China. These developments would imply stronger phase shifts between these two economies, as can be seen from 2001 with the strengthening coherences, and especially gains, in the long and business cycle frequencies, at the expense of the short cycles. So there are some similarities with Hong Kong: an increased power at those two frequencies would reflect an increased dependence on two-way network trade in components and manufactures, and an increased dependence of Taiwan on China for investment opportunities. The fact that this is happening in an economy that is otherwise more closely integrated with the Chinese economy suggests that Taiwan is in transit. She once held a position similar to Hong Kong, but is now becoming part of a single Chinese economic zone. 


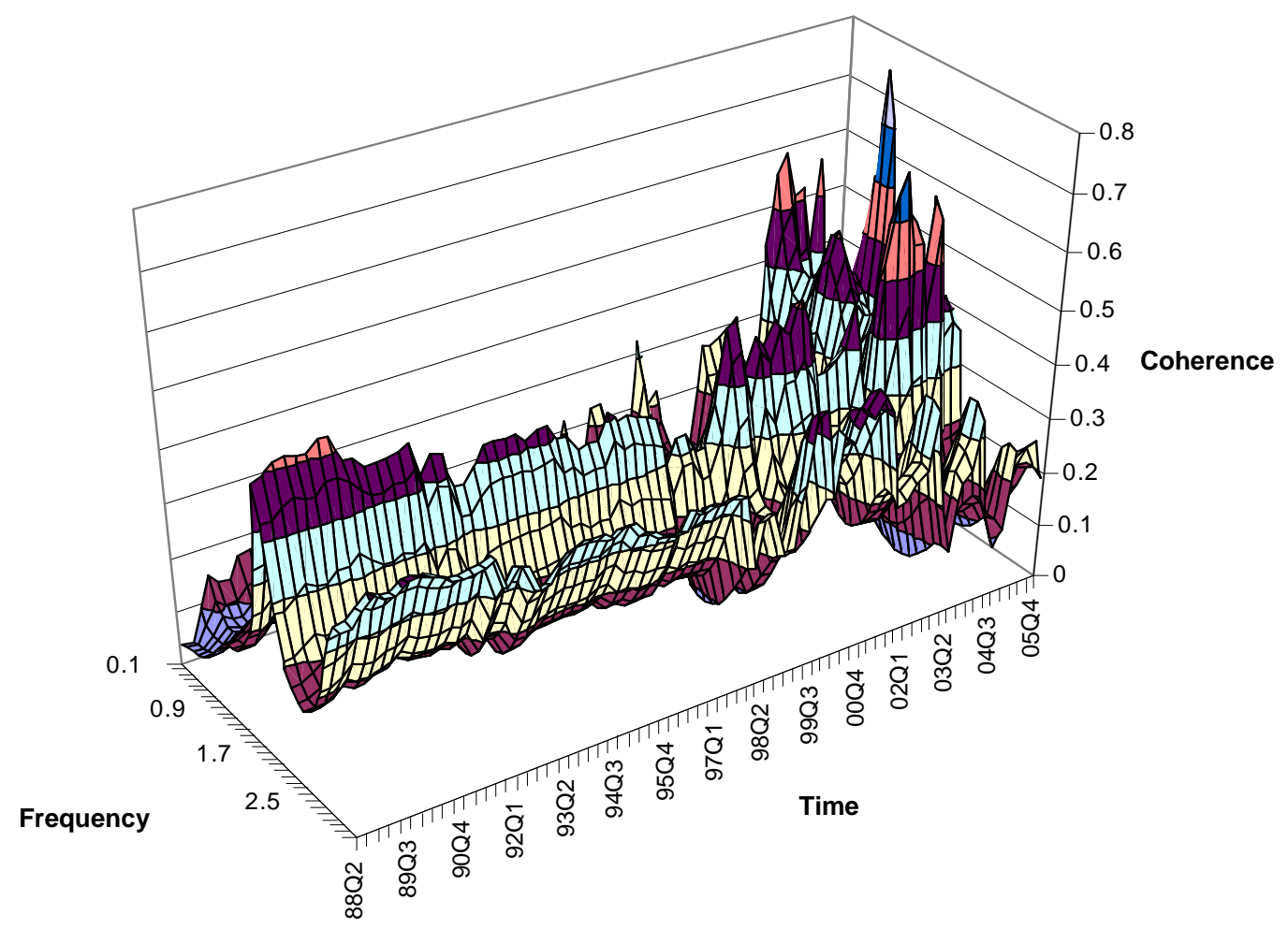

Figure 18: Coherence Taiwan - China

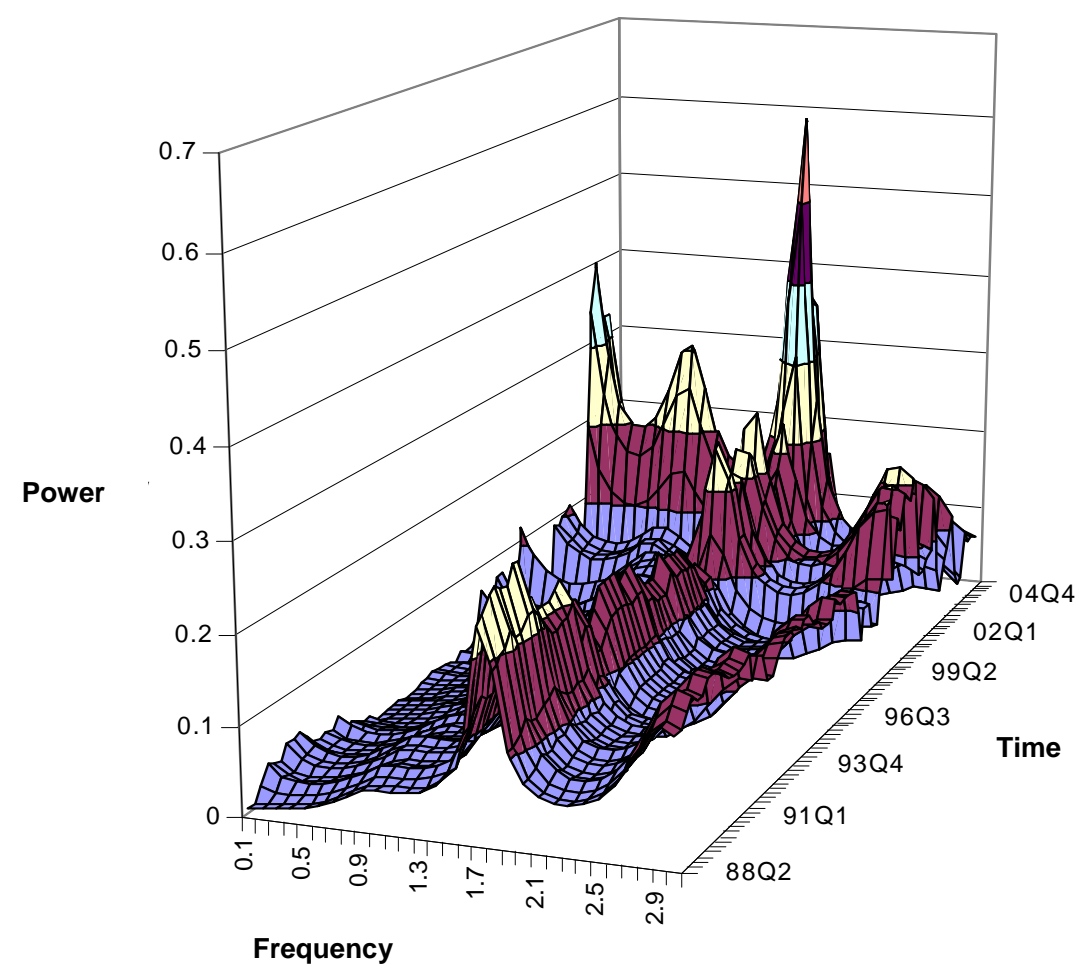

Figure 19: Gains Taiwan - China 


\section{d) Part-time Members of the Chinese Economic Area.}

At this point, we reintroduce the two other economies which appear, from a parallel study of changing economic relationships across the Asia-Pacific area ${ }^{11}$, to be the next most closely linked to the Chinese economy. We do this to provide a contrast; to show that, although Chinese economic hegemony is expanding, it has not (yet) got to the point where these two economies can be considered part of the Chinese economic area in the same way that Taiwan or Hong Kong might be.

The Malaysia-China coherence (figure 20) is relatively low; and has been falling across the board from 2002 onwards, to reach a level of less than 0.1 by 2005 . It also shows a

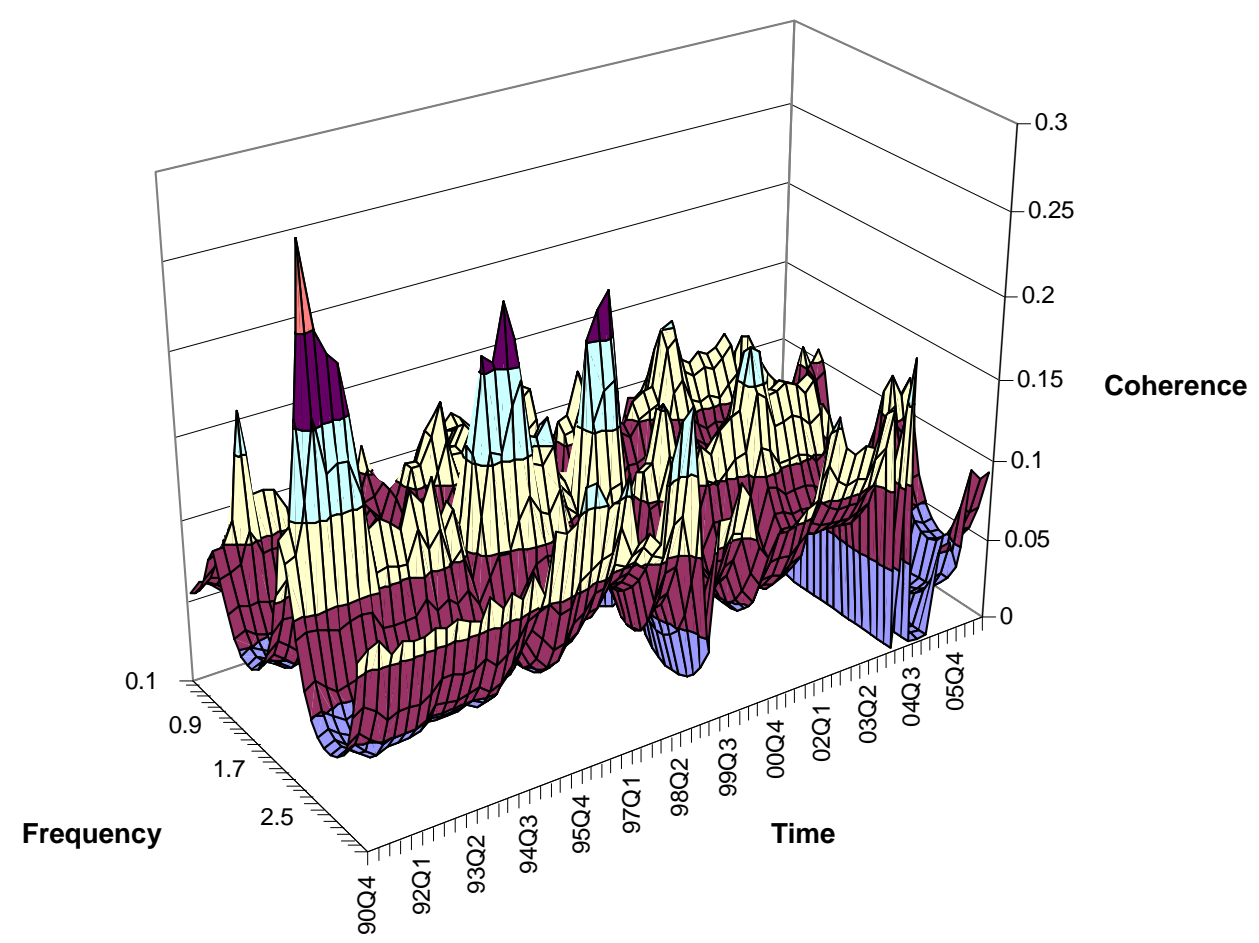

Figure 20: Coherence Malaysia - China

\footnotetext{
${ }^{11}$ Hughes Hallett and Richter (2008).
} 


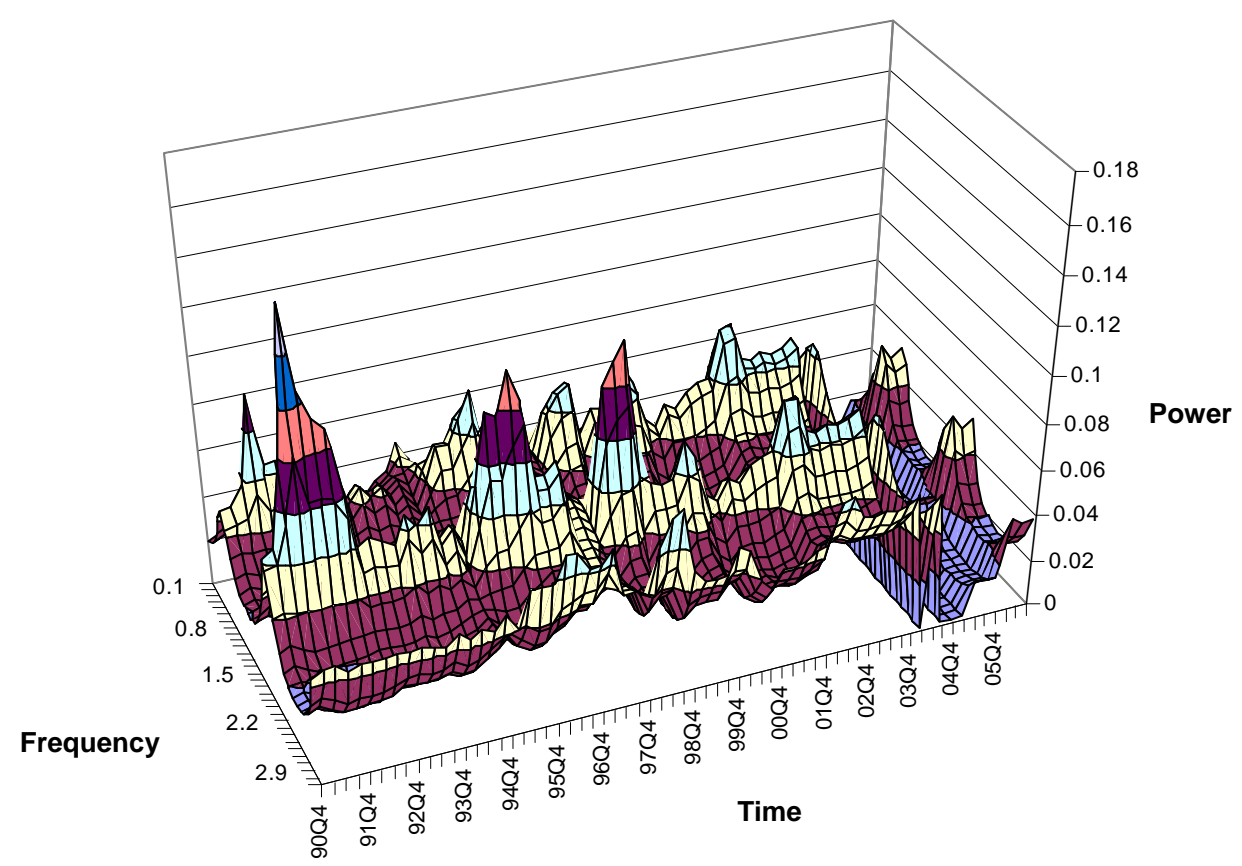

Figure 21: Gains Malaysia - China

significant amount of volatility in the 1990s and during the Asian crisis. This coherence is therefore 4 or 5 times smaller than Malaysia's coherence with Japan, even if larger than her coherence with the US. And it is volatile and declining, unlike the coherence with Japan. Thus, while earlier results may have suggested the opposite, it is hard to argue that Malaysia really is part of an emerging bloc based on China. Given the falling coherence, the most that can be said is that she is a marginal, part-time member who flirted with that bloc but is now drifting away. The gains (figure 21), the impact of China on growth patterns in Malaysia, support that interpretation. These gains are very low and again falling, many times smaller than the effect of Japanese growth and no stronger than the impact of the US. Malaysia's role as supplier of components and materials to Japan therefore dominates. Moreover the gains and coherence with China remain focused at the short, long and business cycle frequencies; no evidence of shifts in phase or in product structure there.

The Singapore-China coherence (figure 22), while similar in some respects, offers a rather different picture. The main feature is a steady increase in the coherence from the late 80 s through to 2001 , then a crash in 2003 , and a sharp recovery (almost to the previous peak) in 2004-6. Moreover, these changes are across the board rather than concentrated on the usual three frequencies. The result is a coherence of 0.2-0.3 after 2000 which, while less than Singapore's coherence with Japan, is comparable with Taiwan's coherence with China and 


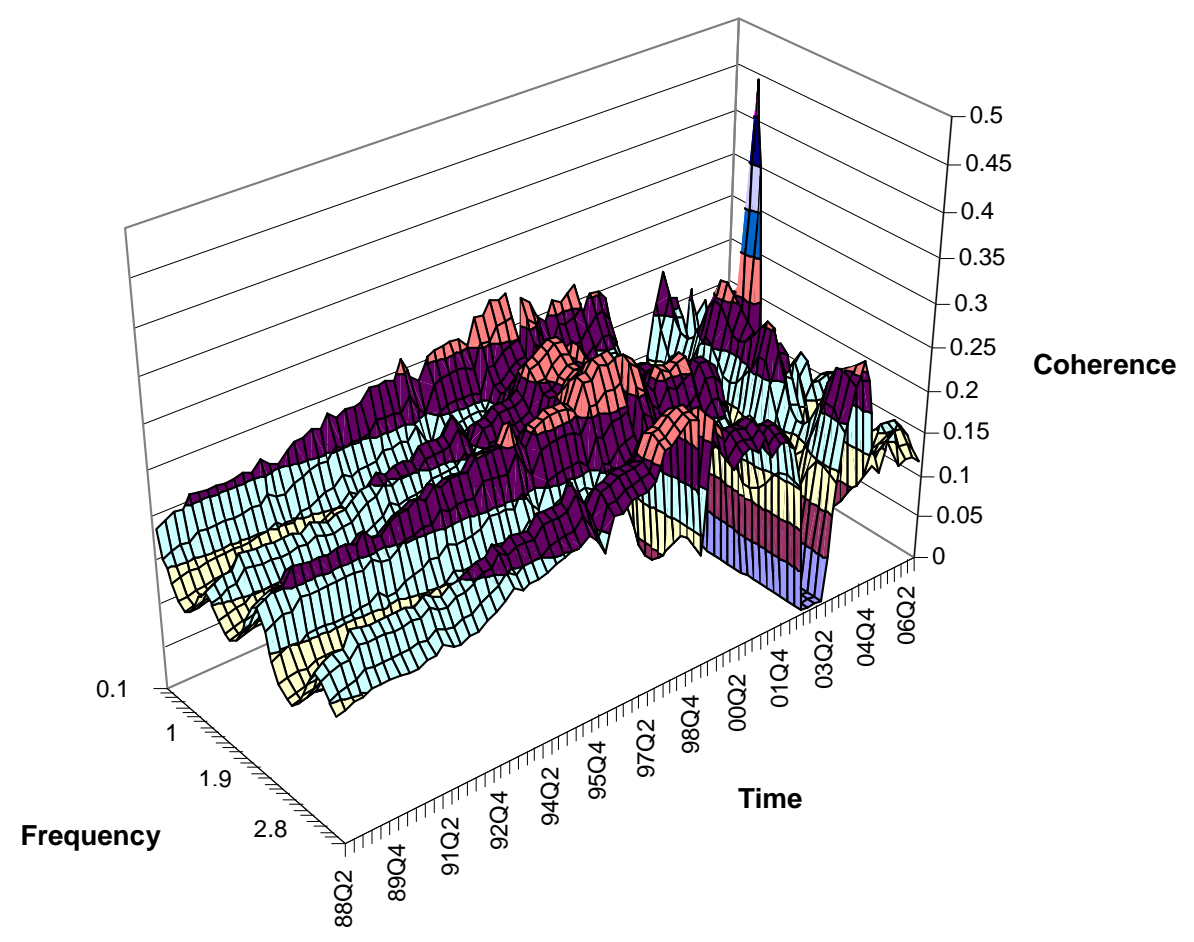

Figure 22: Coherence Singapore - China

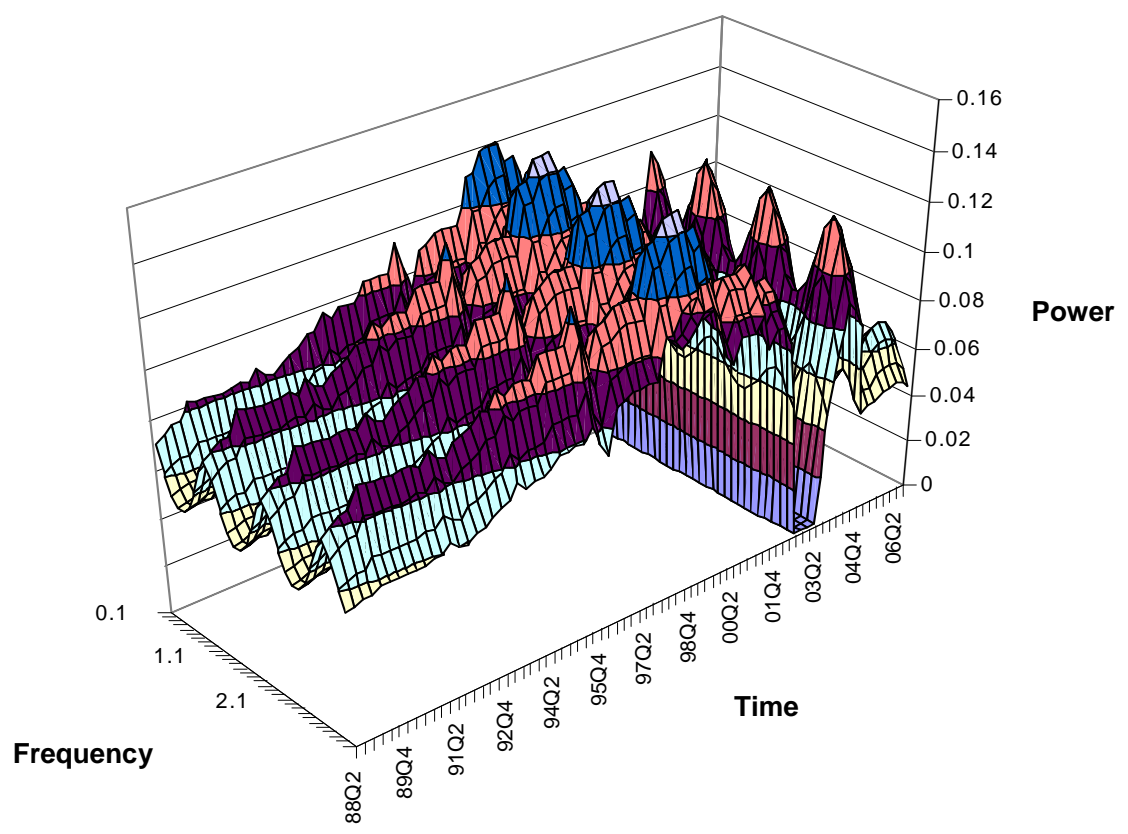

Figure 23: Gains Singapore - China

lower than Hong Kong's with China. On the other hand, it is larger than the inter-bloc coherences with the US, Japan or Malaysia, and consistent with increasing investment and financial links to China since it appears at all frequencies. This looks to be an economy which is building up its links with China without having (yet) reduced those to the US or Japan. The 
gains (figure 23) show a similar picture: increasing across the board, albeit at a considerably lower level of 0.1 , which is less than the spillovers from Japan but more than those from the US. Again, the even spread across frequencies suggest no shifts in phase or product structures which, given the increases in trade in manufactures in the region, and the small manufacturing sector in Singapore, must mean that these particular linkages are based on investment flows.

\section{Conclusions}

The contribution of this paper has been to examine the hypothesis that the economic links and leadership-dependency relationships in the Chinese economic area have changed over the past 20 years. We have used time-varying spectral methods to decompose the growth rates, and the linkages between them, of China, Hong Kong, Taiwan, the US, and two regional comparators (Malaysia, Singapore); and study the coherence, spillover effects, and some changes in leads, lags and product composition, at each cycle length. We find:

a) That the links with the US have indeed weakened, and those within a bloc centred on China have been strengthening.

b) But this is not a new phenomenon. It has been happening since the mid-1980s, although it has been partly, if incompletely, reversed by the recent unbalanced expansion of trade.

c) Convergence between China and her special regions is partial and incomplete. It is stronger between China and Taiwan than between China and Hong Kong. The coherence between China and Hong Kong is strong only at long cycles, with some at business cycles and little at short cycles except in bad times. There is little in the way of gains (spillovers) from China. This is an economy developing separately through specialisation and comparative advantage (in finance, investment, services). Taiwan's performance is a good deal closer to China's. The coherence and gains are now higher at long and business cycle frequencies than they were, but have fallen over time at short cycles. That denotes a shift in phase, and hence an industrial structure that is increasingly linked through network trade, components, and investment. Hence Taiwan shows larger spillovers from China, partially hidden by the shifts in phase.

d) There is little evidence of changing lead/lag relationships which would signal shifts in the industrial or product structures that create the links, except in the China-Taiwan area (and possibly Singapore) which shows increased trade in intermediates, components and financing.

e) The relationship with the US is more complex. It appears that the US still influences the shape and existence of cycles elsewhere through her control of monetary conditions where 
exchange rates are pegged; but the Asians have some control of the size of their own cycles through their trade in consumption and intermediate goods. A similar asymmetric pattern, in a less dramatic form, holds between China and Hong Kong; but not between China and Taiwan, suggesting closer integration in the latter case.

f) There is no evidence that fixed exchange rates have encouraged convergence despite increasing trade and financial links. ${ }^{12}$ If anything the opposite seems to be true. Taiwan with her flexible exchange rate regime has shown the most integration with China, while Hong Kong shows less convergence in the years when her exchange rate was effectively fixed. In those years Hong Kong's coherence increased but the gains did not; implying some similarity in the timing of the longer cycles, but no additional spillovers, industrial linkage or dependence despite the fixed exchange rates ${ }^{13}$. This suggests that the failure of the fixed exchange rates to create deeper convergence is a consequence of the capacity of misaligned or undervalued exchange rates to generate unsuitable monetary conditions - excess liquidity, easy credit, and asset bubbles. Taiwan looks to be a better candidate for currency union than Hong Kong.

\section{References}

Artis, M., and Zhang, W. (1997): International Business Cycles and the ERM: Is there a European Business Cycle? International Journal of Finance and Economics 2, 1-16.

Artis, M., Marcellino, M., and Priorietti, T. (2004): Dating the Euro Area Business Cycle. In L. Reichlin (Ed.): The Euro Area Business Cycle: Stylised Facts and Measurement Issues, Centre for Economic Policy Research, London.

Artis, M., Fidrmuc, J., and Scharler, J. (2008): The Transmission of Business Cycles: Implications for EMU enlargement. Economics of Transition, 16, 559-582.

Barro, R. J., and Sala-I-Martin, X. (1991): Convergence across States and Regions. Brookings Papers on Economic Activity 1.

Barro, R. J., and Sala-I-Martin, X. (1992): Convergence. Journal of Political Economy 100, 223-251.

Baxter, M., and Kouparitsas, M. A. (2005): Determinants of Business Cycle Comovement: a Robust Analysis. Journal of Monetary Economics 52, 113-158.

\footnotetext{
${ }^{12}$ Artis et al (2008) find that financial integration in Europe has an ambiguous effect on cyclical convergence.

${ }^{13}$ This conclusion is consistent with Cavoli and Rajan (2007) who also find Chinese output growth does not cause Hong Kong output growth (marginally vice versa), although inflation in either economy strongly affects output in the other. That suggests relative costs are driving the increased trade between them. That implies specialisation according to mutual advantage, rather than integration as such - a sure sign of independent but linked developments.
} 
Bluestein, L. I. (1968): A linear filtering approach to the computation of the discrete Fourier transform. Northeast Electronics Research and Engineering Meeting Record 10218 219.

Boashash, B. (2003): Time Frequency Signal Analysis and Processing, Elsevier, Oxford.

Boashash, B., and Reilly, A. (1992): Algorithms for time-frequency signal analysis, pp. 163181. In B. Boashash (Ed.): Time-Frequency Signal Analysis - Methods and Applications, Longman-Cheshire, Melbourne.

Canova, F. (1998): Detrending and Business Cycle Facts. Journal of Monetary Economics 41, 475-512.

Canova, F., and Dellas, H. (1993): Trade Dependence and the International Business Cycle. Journal of International Economics 34, 23-47.

Cavoli, T., and Rajan, R. S. (2007): Exploring the Case for Monetary Integration between the Chinese Mainland and Hong Kong. China \& the World Economy 15, 17-34.

Chaplygin, V., Hughes Hallett, A., and Richter, C. R. (2006 ): Monetary Re-integration in the ex-Soviet Union: A Union of Four? . Economics of Transition 14 47-68.

Chauvet, M., and Potter, S. (2001): Recent Changes in the US Business Cycle. Manchester School 69, 481-508.

Demertzis, M., Hughes Hallett, A., and Rummel, O. (1998): "Is a 2-Speed System in Europe the Answer to the Conflict between the German and the Anglo-Saxon Models of Monetary Control", in S. Black and M. Moersch eds., Competition and Convergence in Financial Markets - the German and Anglo-American Models, Elsevier North Holland, New York.

Dowrick, S., and Nguyen, D.-T. (1989): OECD comparative economic growth 1950-85. American Economic Review 79, 1010-1030.

Doyle, B., and Faust, J. (2003): Breaks in the Variability and Comovement of G7 Economic Growth. International Finance Discussion Paper, no 786, Board of Governors, Federal Reserve System, Washington, DC.

Evans, P., and Karras, G. (1996): Convergence revisited. Journal of Monetary Economics 37, 249-265.

Fidrmuc, J., and Batorova, I. (2008): China and the World Economy: A Dynamic Correlation Analysis of Business Cycles. UNU-WIDER DP 2008/02 United Nations, Helsinki.

Frankel, J., and Rose, A. (1998): The Endogeneity of the Optimal Currency Area Criteria. Economic Journal 108, 1009-25.

Frankel, J., and Rose, A. (1998): An Estimate of the Effect of a Common Currency on Trade and Income. Quaterly Journal of Economics, 117, 437-66.

Gerlach, S. (1989): Information, Persistence, and real Business Cycles. Journal of Economic Dynamics and Control 13, 187-199.

Harding, D., and Pagan, A. (2001): Extracting, Analysing and Using Cyclical Information: mimeo, Australian National University.

Hughes Hallett, A., and Piscitelli, L. (2002): Does Trade Cause Convergenve? Economics Letters 75, 165-170.

Hughes Hallett, A., and Richter, C. (2002): Are Capital Markets Efficient? Evidence from the Term Structure of Interest Rates in Europe. Economic and Social Review 33, 333 - 56. 
Hughes Hallett, A., and Richter, C. (2003a): Learning and Monetary Policy in a Spectral Analysis Representation, pp. 91-103. In P. Wang, and S.-H. Chen (Eds): Computational Intelligence in Economics and Finance, Springer Verlag, Berlin.

Hughes Hallett, A., and Richter, C. (2003b): A Spectral Analysis of the Short-End of the British Term Structure, pp. 123-128. In R. Neck (Ed.): Modelling and Control of Economic Systems, Elsevier, Amsterdam.

Hughes Hallett, A., and Richter, C. (2004): Spectral Analysis as a Tool for Financial Policy: An Analysis of the Short End of the British Term Structure. Computational Economics 23, 271-288.

Hughes Hallett, A., and Richter, C. (2006): "Is the Convergence of Business Cycles a Global or Regional Issue? The US, UK, and Euroland" International Journal of Finance and Economics, 11, 177-94.

Hughes Hallett, A., and Richter, C. (2008): "Measuring Spillover and Convergence Effects in the Asia-Pacific Region" in (eds) R. Rajan, S. Thangavelu and R. Parinduri, "Monetary, Exchange Rate and Financial Issues and Policies in Asia", World Scientific Press, Singapore and New Jersey.

Inklaar, R., and de Haan, J. (2000): Is there really a European Business Cycle? CESifo Working Paper No 268, CESifo, Munich.

Jenkins, G. M., and Watts, D. G. (1968): Spectral Analysis and its Applications. Holden-Day. San Francisco.

Kalemli-Ozcan, S., Sorenson, B., and Yosha, O. (2001): Economic Integration, Industrial Specialisation, and the Asymmetry of Macroeconomic Fluctuations. Journal of International Economics 55, 107-137.

Kalemli-Ozcan, S., Sorensen, B. E., and Yosha, O. (2003): Risk Sharing and Industrial Specialisation: Regional and International Evidence American Economic Review 93, 903-918.

Kocenda, E., and Hanousek, J. (1998): Integration of Emerging Equity Markets: Major Asian Players. Korean Economic Review 14, 99-114.

LaMotte, L. R., and McWorther, A. J. (1978): An exact test for the presence of random walk coefficients in a linear regression. Journal of the American Statistical Association 73, 816-820.

Laven, G., and Shi, G. (1993): Zur Interpretation von Lagverteilungen: Discussion Paper, Johannes Gutenberg University, Mainz.

Lin, Z. (1997): An Introduction to Time-Frequency Signal Analysis. Sensor Review 17, 4653.

Mankiw, N. G., Romer, D., and Weil, D. (1992): A Contribution to the Empirics of Economic Growth. Quarterly Journal of Economics 107, 407-437.

Nerlove, M., Grether, D. M., and Carvalho, J. L. (1995): Analysis of Economic Time Series. Academic Press. New York.

Peersman, G., and Smets, F. (2005): Industry Effects of Monetary Policy in the Euro Area. Economic Journal 115, 319-342.

Ploberger, W., Krämer, W., and Kontrus, K. (1989): A New Test For Structural Stability in the Linear Regression Model. Journal of Econometrics 40, 307-318. 
Quah, D. T. (1993): Galton's Fallacy and Tests of the Convergence Hypothesis. Scandinavian Journal of Economics 95, 427-443.

Rabiner, L. R., Schafer, R. W., and Rader, C. M. (1969): The chirp z-transform algorithm and its application Bell System Technical Journal 48, 1249-1292.

Shin, K., and Wang, Y. (2004): Trade Integration and Business Cycle Co-movements: the case of Korea with other Asian countries Japan and the World Economy 16, 213-230.

Sato, K., and Zhang, Z. (2006): Real Output Co-movements in East Asia: any evidence for a monetary union? World Economy 29, 1671-1689.

Shin, K., and Sohn, C.-H. (2006): Trade and Financial Integration in East Asia: effects on comovements. World Economy 29, 1649-1669.

Stock, J. H., and Watson, M. W. (2002): Has the Business Cycle Changed and Why? NBER Working paper No 9127, Cambridge, MA.

Stock, J. H., and Watson, M. W. (2005): Understanding Changes in the International Business Cycles. Journal of the European Economic Association, 3, 966-1006.

Wells, C. (1996): The Kalman Filter in Finance. Kluwer Academic Publishers. Dordrecht.

Wolff, E. N. (1991): Capital formation and productivity convergence over the long term. American Economic Review 81, 565-579.

Wolters, J. (1980): Stochastic Dynamic Properties of Linear Econometric Models. Springer Verlag. Berlin. 


\section{APPENDIX: The Time Domain Regression Results}

\begin{tabular}{|c|c|c|c|}
\hline \multicolumn{4}{|c|}{ VAR/System - Estimation by Kalman Filter } \\
\hline Dependent Variable & DLUSGDP & Quarterly Data From & $1981: 04$ to $2006: 01$ \\
\hline Usable Observations & 87 & Degrees of Freedom & 79 \\
\hline Centered $\mathrm{R}^{2}$ & 0.2804 & $\mathrm{R} \mathrm{Bar}^{2}$ & 0.2440 \\
\hline Uncentered $\mathrm{R}^{2}$ & 0.7335 & $\mathrm{~T} * \mathrm{R}^{2}$ & 61.617 \\
\hline $\begin{array}{l}\text { Mean of Dependent } \\
\text { Variable }\end{array}$ & 0.0079 & $\begin{array}{l}\text { Std Error of } \\
\text { Dependent Variable }\end{array}$ & 0.0061 \\
\hline $\begin{array}{l}\text { Standard Error of } \\
\text { Estimate }\end{array}$ & 0.0053 & $\begin{array}{l}\text { Sum of Squared } \\
\text { Residuals }\end{array}$ & 0.0022 \\
\hline Akaike (AIC) Criterion & 0.0058 & $\begin{array}{l}\text { Ljung-Box Test: } \\
\mathrm{Q}^{*}(9)\end{array}$ & 18.1554 \\
\hline Variable & Coeff & Std Error & T-Stat \\
\hline Constant & 0.0021 & 0.0018 & 1.1368 \\
\hline $\operatorname{DLUSGDP}\{1\}$ & 0.3173 & 0.0932 & 3.4043 \\
\hline $\operatorname{DLUSGDP}\{2\}$ & 0.2615 & 0.0896 & 2.9172 \\
\hline $\operatorname{DLUSGDP}\{5\}$ & -0.1835 & 0.0809 & -2.2677 \\
\hline DLUSGDP $\{9\}$ & 0.1583 & 0.0669 & 2.3679 \\
\hline
\end{tabular}

Table 1: Regression Results of the US Growth Rate

\begin{tabular}{||l|l|l|l||}
\hline \multicolumn{4}{|c|}{ VAR/System - Estimation by Kalman Filter } \\
\hline Dependent Variable & DLCHGDP & Quarterly Data From & $1986: 03$ to 2006:03 \\
\hline Usable Observations & 81 & $\begin{array}{l}\text { Std Error of } \\
\text { Dependent Variable }\end{array}$ & 0.0502523692 \\
\hline $\mathrm{R}^{2}$ & 0.62668 & $\begin{array}{l}\text { Standard Error of } \\
\text { Estimate }\end{array}$ & 0.0517675790 \\
\hline $\begin{array}{l}\text { Mean of Dependent } \\
\text { Variable }\end{array}$ & 0.0192415504 & $\begin{array}{l}\text { Sum of Squared } \\
\text { Residuals }\end{array}$ & 0.2090308143 \\
\hline $\begin{array}{l}\text { Akaike (AIC) Criterion } \\
\text { Variable }\end{array}$ & 0.06003 & $\begin{array}{l}\text { Ljung-Box Test: } \\
\text { Q*(18) }\end{array}$ & 15.8562 \\
\hline Constant & Coeff & Std Error & T-Stat \\
\hline DLCHGDP $\{3\}$ & 0.0309714823 & 0.028215885321 & 1.097661190261 \\
\hline DLCHGDP $\{4\}$ & 0.0230286004 & 0.125233414390 & 0.18388543089 \\
\hline
\end{tabular}

Table 2: Regression Results for the Chinese Growth Rate 


\begin{tabular}{||l|l|l|l||}
\hline \multicolumn{4}{|c||}{ VAR/System - Estimation by Kalman Filter } \\
\hline Dependent Variable & DLHKGDP & Quarterly Data From & 1975:01 to 2007:02 \\
\hline Usable Observations & 130 & $\begin{array}{l}\text { Std Error of } \\
\text { Dependent Variable }\end{array}$ & 0.0234703383 \\
\hline $\mathrm{R}^{2}$ & 0.53162 & $\begin{array}{l}\text { Standard Error of } \\
\text { Estimate }\end{array}$ & 0.0219456332 \\
\hline $\begin{array}{l}\text { Mean of Dependent } \\
\text { Variable }\end{array}$ & 0.0154963654 & $\begin{array}{l}\text { Sum of Squared } \\
\text { Residuals }\end{array}$ & 0.0606829629 \\
\hline Akaike (AIC) Criterion & 0.02334 & $\begin{array}{l}\text { Ljung-Box Test: } \\
\text { Q*(23) }\end{array}$ & 25.2098 \\
\hline Variable & Coeff & Std Error & T-Stat \\
\hline Constant & 0.017568444 & 0.007602695572 & 2.299121853247 \\
\hline DLHKGDP $\{4\}$ & 0.142625783 & 0.094915502433 & 1.500001698574 \\
\hline DLHKGDP $\{5\}$ & 0.066241805 & 0.098722764054 & -0.665128943392 \\
\hline DLHKGDP $\{7\}$ & -0.185456412 & 0.033830172124 & -5.326375731085 \\
\hline
\end{tabular}

Table 3: The Regression Results for Hong Kong

\begin{tabular}{||l|l|l|l||}
\hline \multicolumn{4}{|c|}{ VAR/System - Estimation by Kalman Filter } \\
\hline Dependent Variable & DLSINGDP & Quarterly Data From & $1986: 03$ to 2006:03 \\
\hline Usable Observations & 81 & $\begin{array}{l}\text { Std Error of } \\
\text { Dependent Variable }\end{array}$ & 0.0171311541 \\
\hline $\mathrm{R}^{2}$ & 0.64952 & $\begin{array}{l}\text { Standard Error of } \\
\text { Estimate }\end{array}$ & 0.0186355555 \\
\hline $\begin{array}{l}\text { Mean of Dependent } \\
\text { Variable }\end{array}$ & 0.0168263215 & $\begin{array}{l}\text { Sum of Squared } \\
\text { Residuals }\end{array}$ & 0.0270881464 \\
\hline $\begin{array}{l}\text { Akaike (AIC) Criterion } \\
\text { Variable }\end{array}$ & 0.02161 & $\begin{array}{l}\text { Ljung-Box Test: } \\
\text { Q*(18) }\end{array}$ & 22.4491 \\
\hline Constant & Coeff & Std Error & T-Stat \\
\hline DLSINGDP $\{3\}$ & 0.010252154 & 0.009367828253 & 1.094400278266 \\
\hline DLSINGDP $\{7\}$ & -0.181030613 & 0.028667991134 & -6.31472964133 \\
\hline
\end{tabular}

Table 4: Regression Results of the Singapore Growth Rate 


\begin{tabular}{||l|l|l|l||}
\hline \multicolumn{4}{|c|}{ VAR/System - Estimation by Kalman Filter } \\
\hline Dependent Variable & DLMAGDP & Quarterly Data From & $1989: 03$ to 2006:03 \\
\hline Usable Observations & 69 & $\begin{array}{l}\text { Std Error of } \\
\text { Dependent Variable }\end{array}$ & 0.0183531831 \\
\hline $\mathrm{R}^{2}$ & 0.74586 & $\begin{array}{l}\text { Standard Error of } \\
\text { Estimate }\end{array}$ & 0.0209841546 \\
\hline $\begin{array}{l}\text { Mean of Dependent } \\
\text { Variable }\end{array}$ & 0.0153163073 & $\begin{array}{l}\text { Sum of Squared } \\
\text { Residuals }\end{array}$ & 0.0286217583 \\
\hline $\begin{array}{l}\text { Akaike (AIC) Criterion } \\
\text { Variable }\end{array}$ & 0.02646 & $\begin{array}{l}\text { Ljung-Box Test: } \\
\text { Q*(16) }\end{array}$ & 14.7848 \\
\hline Constant & Coeff & Std Error & T-Stat \\
\hline DLMAGDP $\{2\}$ & 0.009395516 & 0.011980904806 & 0.784207543108 \\
\hline DLMAGDP $\{4\}$ & -0.087383659 & 0.045952037273 & -1.901627535519 \\
\hline DLMAGDP $\{5\}$ & 0.148599308 & 0.036901972156 & 4.026866286733 \\
\hline
\end{tabular}

Table 5: Regression Results of the Malaysian Growth Rate

\begin{tabular}{||l|l|l|l||}
\hline \multicolumn{4}{|c|}{ VAR/System - Estimation by Kalman Filter } \\
\hline Dependent Variable & DLTWGDP & Quarterly Data From & $1983: 01$ to 2005:04 \\
\hline Usable Observations & 92 & $\begin{array}{l}\text { Std Error of } \\
\text { Dependent Variable }\end{array}$ & 0.0139569693 \\
\hline $\mathrm{R}^{2}$ & 0.79728 & $\begin{array}{l}\text { Standard Error of } \\
\text { Estimate }\end{array}$ & 0.0146350797 \\
\hline $\begin{array}{l}\text { Mean of Dependent } \\
\text { Variable }\end{array}$ & 0.0152445775 & $\begin{array}{l}\text { Sum of Squared } \\
\text { Residuals }\end{array}$ & 0.0186341436 \\
\hline Akaike (AIC) Criterion & 0.01819 & $\begin{array}{l}\text { Ljung-Box Test: } \\
\text { Q*(20) }\end{array}$ & 20.2988 \\
\hline Variable & Coeff & Std Error & T-Stat \\
\hline Constant & -0.005849844 & 0.006370443274 & -0.918278881548 \\
\hline DLTWNGDP $\{4\}$ & 0.360379895 & 0.062253658774 & 5.788895020231 \\
\hline DLTWGDP $\{5\}$ & -0.208082158 & 0.059556588314 & -3.49385624196 \\
\hline DLTWGDP $\{7\}$ & 0.281457283 & 0.146744059412 & 1.91801483563 \\
\hline DLTWGDP $\{8\}$ & 0.367353933 & 0.035917257508 & 10.22778347069 \\
\hline
\end{tabular}

Table 6: Regression Results for Taiwan 


\begin{tabular}{||l|l|l|l||}
\hline \multicolumn{4}{|c|}{ VAR/System - Estimation by Kalman Filter } \\
\hline Dependent Variable & DLCHGDP & Quarterly Data From & $1986: 03$ to 2006:03 \\
\hline Usable Observations & 81 & $\begin{array}{l}\text { Std Error of } \\
\text { Dependent Variable }\end{array}$ & 0.0502523692 \\
\hline $\mathrm{R}^{2}$ & 0.75146 & $\begin{array}{l}\text { Standard Error of } \\
\text { Estimate }\end{array}$ & 0.0886966903 \\
\hline $\begin{array}{l}\text { Mean of Dependent } \\
\text { Variable }\end{array}$ & 0.0192415504 & $\begin{array}{l}\text { Sum of Squared } \\
\text { Residuals }\end{array}$ & 0.2389229410 \\
\hline $\begin{array}{l}\text { Akaike (AIC) Criterion } \\
\text { Variable }\end{array}$ & 0.10286 & $\begin{array}{l}\text { Ljung-Box Test: } \\
\text { Q*(18) }\end{array}$ & 18.8275 \\
\hline Constant & Coeff & Std Error & T-Stat \\
\hline DLCHGDP $\{4\}$ & -0.011188398 & 0.029987965239 & -0.373096280996 \\
\hline DLUSGDP $\{5\}$ & 0.113482839 & 0.115247578376 & 0.984687407113 \\
\hline
\end{tabular}

Table 7: Regression Results between China and the US

\begin{tabular}{||l|l|l|l||}
\hline \multicolumn{4}{|c||}{ VAR/System - Estimation by Kalman Filter } \\
\hline Dependent Variable & DLUSGDP & Quarterly Data From & $1986: 03$ to 2006:03 \\
\hline Usable Observations & 81 & $\begin{array}{l}\text { Std Error of } \\
\text { Dependent Variable }\end{array}$ & 0.5064543417 \\
\hline $\mathrm{R}^{2}$ & 0.66606 & $\begin{array}{l}\text { Standard Error of } \\
\text { Estimate }\end{array}$ & 0.5080642573 \\
\hline $\begin{array}{l}\text { Mean of Dependent } \\
\text { Variable }\end{array}$ & 0.0192415504 & $\begin{array}{l}\text { Sum of Squared } \\
\text { Residuals }\end{array}$ & 20.134084588 \\
\hline $\begin{array}{l}\text { Akaike (AIC) Criterion } \\
\text { Variable }\end{array}$ & 0.58919 & $\begin{array}{l}\text { Ljung-Box Test: } \\
\text { Q*(18) }\end{array}$ & 17.8252 \\
\hline Constant & Coeff & Std Error & T-Stat \\
\hline DLUSGDP $\{2\}$ & 0.4585070334 & 0.294045977540 & 1.559303879218 \\
\hline DLCHGDP $\{5\}$ & 0.1454246122 & 0.019634219737 & 7.40669168996 \\
\hline
\end{tabular}

Table 8: Regression Results US - China 


\begin{tabular}{||l|l|l|l||}
\hline \hline \multicolumn{4}{|c|}{ VAR/System - Estimation by Kalman Filter } \\
\hline Dependent Variable & DLTWGDP & Quarterly Data From & $1983: 01$ to 2005:04 \\
\hline Usable Observations & 92 & $\begin{array}{l}\text { Std Error of } \\
\text { Dependent Variable }\end{array}$ & 0.0139569693 \\
\hline $\mathrm{R}^{2}$ & 0.76803 & $\begin{array}{l}\text { Standard Error of } \\
\text { Estimate }\end{array}$ & 0.0128766272 \\
\hline $\begin{array}{l}\text { Mean of Dependent } \\
\text { Variable }\end{array}$ & 0.0152445775 & $\begin{array}{l}\text { Sum of Squared } \\
\text { Residuals }\end{array}$ & 0.0144252550 \\
\hline Akaike (AIC) Criterion & 0.01405 & $\begin{array}{l}\text { Ljung-Box Test: } \\
\text { Q*(20) }\end{array}$ & 19.3837 \\
\hline Variable & Coeff & Std Error & T-Stat \\
\hline Constant & 0.006747327 & 0.002159098975 & 3.125066254195 \\
\hline DLTWGDP $\{4\}$ & 0.649847780 & 0.228228873018 & 2.84735130632 \\
\hline DLTWGDP $\{5\}$ & -0.143168066 & 0.030501660391 & -4.69377942707 \\
\hline DLTWGDP $\{7\}$ & 0.123711789 & 0.375670877929 & 0.329308968585 \\
\hline DLUSGDP $\{5\}$ & -0.006524062 & 0.002519519248 & -2.58940766567 \\
\hline
\end{tabular}

Table 9: Regression Results Taiwan - US

\begin{tabular}{||l|l|l|l||}
\hline \multicolumn{5}{|c|}{ VAR/System - Estimation by Kalman Filter } \\
\hline Dependent Variable & DLHKGDP & Quarterly Data From & $1975: 01$ to 2006:03 \\
\hline Usable Observations & 130 & $\begin{array}{l}\text { Std Error of } \\
\text { Dependent Variable }\end{array}$ & 0.0234703383 \\
\hline$R^{2}$ & 0.99127 & $\begin{array}{l}\text { Standard Error of } \\
\text { Estimate }\end{array}$ & 0.0272084849 \\
\hline $\begin{array}{l}\text { Mean of Dependent } \\
\text { Variable }\end{array}$ & 0.0154963654 & $\begin{array}{l}\text { Sum of Squared } \\
\text { Residuals }\end{array}$ & 0.0895764999 \\
\hline Akaike (AIC) Criterion & 0.02990 & $\begin{array}{l}\text { Ljung-Box Test: } \\
\text { Q*(22) }\end{array}$ & 21.0561 \\
\hline Variable & Coeff & Std Error & T-Stat \\
\hline Constant & 0.017326208 & 0.003667200929 & 4.72464115391 \\
\hline DLHKGDP $\{1\}$ & -0.746159905 & 0.183086711489 & -4.07544545094 \\
\hline DLHKGDP $\{4\}$ & 0.504466845 & 0.165941283482 & 3.04003220146 \\
\hline DLUSGDP $\{3\}$ & 0.004511100 & 0.040514529151 & 0.111345230926 \\
\hline DLUSGDP $\{5\}$ & 0.001276565 & 0.000506077907 & 2.52246739273 \\
\hline DLUSGDP $\{6\}$ & -0.002998252 & 0.000902216478 & -3.32320734028 \\
\hline
\end{tabular}

Table 10: Regression Results Hong Kong - US 


\begin{tabular}{||l|l|l|l||}
\hline \multicolumn{4}{|c|}{ VAR/System - Estimation by Kalman Filter } \\
\hline Dependent Variable & DLHKGDP & Quarterly Data From & $1987: 01$ to 2006:03 \\
\hline Usable Observations & 79 & Std Error of Dep. Variable & 0.0234703383 \\
\hline $\mathrm{R}^{2}$ & 0.62308 & Std Error of Estimate & 0.0169685714 \\
\hline Mean of Dep. Variable & 0.0154963654 & Sum of Squared Residuals & 0.0213069988 \\
\hline Akaike (AIC) Criterion & 0.01926 & Ljung-Box Test: Q* $(17)$ & 18.1543 \\
\hline Variable & Coeff & Std Error & T-Stat \\
\hline Constant & 0.008617812 & 0.000649762839 & 13.26301161179 \\
\hline DLHKGDP $\{4\}$ & 0.107800119 & 0.026725060640 & 4.033671626886 \\
\hline DLHKGDP $\{6\}$ & -0.082371113 & 0.459059667154 & -0.179434436646 \\
\hline DLCHGDP & 0.069849257 & 0.063412732720 & 1.101502081038 \\
\hline DLCHGDP $\{1\}$ & 0.088334231 & 0.048934013255 & 1.80517038325 \\
\hline \hline
\end{tabular}

Table 11: Regression Results Hong Kong - China

\begin{tabular}{||l|l|l|l||}
\hline \multicolumn{4}{|c|}{ VAR/System - Estimation by Kalman Filter } \\
\hline Dependent Variable & DLTWGDP & Quarterly Data From & $1987: 01$ to 2005:04 \\
\hline Usable Observations & 76 & Std Error of Dep. Variable & 0.0139569693 \\
\hline $\mathrm{R}^{2}$ & 0.49063 & Std Error of Estimate & 0.0120689219 \\
\hline Mean of Dep. Variable & 0.0152445775 & Sum of Squared Residuals & 0.0101961213 \\
\hline Akaike (AIC) Criterion & 0.01413 & Ljung-Box Test: Q*(17) & 20.4284 \\
\hline Variable & Coeff & Std Error & T-Stat \\
\hline Constant & 0.004103561 & 0.001642566927 & 2.498261111614 \\
\hline DLTWGDP $\{4\}$ & 0.356634863 & 0.063574821887 & 5.60968718137 \\
\hline DLTWGDP $\{5\}$ & -0.189537240 & 0.034258617322 & -5.532542037731 \\
\hline DLTWGDP $\{7\}$ & 0.392471535 & 0.062588689845 & 6.270646283472 \\
\hline DLCHGDP $\{1\}$ & 0.046639541 & 0.015589062827 & 2.99181172955 \\
\hline DLCHGDP $\{2\}$ & -0.080797431 & 0.055903333379 & -1.445306138311 \\
\hline
\end{tabular}

Table 12: Regression Results Taiwan - China 


\begin{tabular}{||l|l|l|l||}
\hline \multicolumn{4}{|c|}{ VAR/System - Estimation by Kalman Filter } \\
\hline Dependent Variable & DLMAGDP & Quarterly Data From & $1989: 03$ to 2006:03 \\
\hline Usable Observations & 69 & $\begin{array}{l}\text { Std Error of } \\
\text { Dependent Variable }\end{array}$ & 0.0183531831 \\
\hline $\mathrm{R}^{2}$ & 0.77453 & $\begin{array}{l}\text { Standard Error of } \\
\text { Estimate }\end{array}$ & 0.0189803705 \\
\hline $\begin{array}{l}\text { Mean of Dependent } \\
\text { Variable }\end{array}$ & 0.0153163073 & $\begin{array}{l}\text { Sum of Squared } \\
\text { Residuals }\end{array}$ & 0.0234165401 \\
\hline $\begin{array}{l}\text { Akaike (AIC) Criterion } \\
\text { Variable }\end{array}$ & 0.02061 & $\begin{array}{l}\text { Ljung-Box Test: } \\
\text { Q*(16) }\end{array}$ & 12.5766 \\
\hline Constant & Coeff & Std Error & T-Stat \\
\hline DLMAGDP $\{4\}$ & 0.016713456 & 0.010685827830 & 1.564076861731 \\
\hline DLMAGDP $\{5\}$ & 0.061261665 & 0.105116604691 & 0.582797218163 \\
\hline DLCHGDP $\{7\}$ & -0.515239204 & 0.131678428115 & -3.912859616751 \\
\hline
\end{tabular}

Table 13: Regression Results Malaysia - China

\begin{tabular}{||l|l|l|l||}
\hline \multicolumn{4}{|c|}{ VAR/System - Estimation by Kalman Filter } \\
\hline Dependent Variable & DLSINGDP & Quarterly Data From & $1988: 02$ to 2006:03 \\
\hline Usable Observations & 79 & $\begin{array}{l}\text { Std Error of } \\
\text { Dependent Variable }\end{array}$ & 0.0171311541 \\
\hline $\mathrm{R}^{2}$ & 0.490527 & $\begin{array}{l}\text { Standard Error of } \\
\text { Estimate }\end{array}$ & 0.0174691118 \\
\hline $\begin{array}{l}\text { Mean of Dependent } \\
\text { Variable }\end{array}$ & 0.0168263215 & $\begin{array}{l}\text { Sum of Squared } \\
\text { Residuals }\end{array}$ & 0.0231929100 \\
\hline $\begin{array}{l}\text { Akaike (AIC) Criterion } \\
\text { Variable }\end{array}$ & 0.02026 & $\begin{array}{l}\text { Ljung-Box Test: } \\
\text { Q*(17) }\end{array}$ & 26.4851 \\
\hline Constant & Coeff & Std Error & T-Stat \\
\hline DLSINGDP $\{7\}$ & 0.0088881345 & 0.002370360189 & 3.749697839060 \\
\hline DLCHGDP & 0.2089789677 & 0.048029410833 & 4.351062485029 \\
\hline
\end{tabular}

Table 14: Regression Results Singapore - China 